\title{
Article \\ Challenging Mimickers in the Diagnosis of Sarcoidosis: A Case Study
}

\author{
Thomas El Jammal ${ }^{1}$, Yvan Jamilloux ${ }^{1}{ }^{\circledR}$, Mathieu Gerfaud-Valentin ${ }^{1}{ }^{\circledR}$, Gaëlle Richard-Colmant ${ }^{1}$, \\ Emmanuelle Weber ${ }^{1}$, Arthur Bert ${ }^{1}$, Géraldine Androdias ${ }^{2}$ and Pascal Sève ${ }^{1,3, *(1)}$ \\ 1 Department of Internal Medicine, Lyon University Hospital, 69004 Lyon, France; \\ thomas_3901@hotmail.fr (T.E.J.); yvan.jamilloux@chu-lyon.fr (Y.J.); \\ mathieu.gerfaud-valentin@chu-lyon.fr (M.G.-V.); gaelle.richard-colmant@chu-lyon.fr (G.R.-C.); \\ emmanuelle.weber@chu-lyon.fr (E.W.); arthur.bert@chu-lyon.fr (A.B.) \\ 2 Department of Neurology, Service Sclérose en Plaques, Pathologies de la Myéline et Neuro-Inflammation, \\ Hôpital Neurologique Pierre Wertheimer, Lyon University Hospital, F-69677 Bron, France; \\ geraldine.androdias-condemine@chu-lyon.fr \\ 3 Research on Healthcare Performance (RESHAPE), INSERM U1290, 69373 Lyon, France \\ * Correspondence: pascal.seve@chu-lyon.fr; Tel.: +33-426-732-636
}

check for

updates

Citation: El Jammal, T.; Jamilloux, Y.; Gerfaud-Valentin, M.;

Richard-Colmant, G.; Weber, E.; Bert,

A.; Androdias, G.; Sève, P.

Challenging Mimickers in the

Diagnosis of Sarcoidosis:

A Case Study. Diagnostics 2021, 11,

1240. https://doi.org/10.3390/

diagnostics 11071240

Academic Editor: Claudio Tana

Received: 16 June 2021

Accepted: 7 July 2021

Published: 12 July 2021

Publisher's Note: MDPI stays neutral with regard to jurisdictional claims in published maps and institutional affiliations.

Copyright: (c) 2021 by the authors. Licensee MDPI, Basel, Switzerland. This article is an open access article distributed under the terms and conditions of the Creative Commons Attribution (CC BY) license (https:/ / creativecommons.org/licenses/by/ $4.0 /)$.

\begin{abstract}
Sarcoidosis is a systemic granulomatous disease of unknown cause characterized by a wide variety of presentations. Its diagnosis is based on three major criteria: a clinical presentation compatible with sarcoidosis, the presence of non-necrotizing granulomatous inflammation in one or more tissue samples, and the exclusion of alternative causes of granulomatous disease. Many conditions may mimic a sarcoid-like granulomatous reaction. These conditions include infections, neoplasms, immunodeficiencies, and drug-induced diseases. Moreover, patients with sarcoidosis are at risk of developing opportunistic infections or lymphoma. Reliably confirming the diagnosis of sarcoidosis and better identifying new events are major clinical problems in daily practice. To address such issues, we present seven emblematic cases, seen in our department, over a ten-year period along with a literature review about case reports of conditions misdiagnosed as sarcoidosis.
\end{abstract}

Keywords: sarcoidosis; diagnosis; lymphoma; opportunistic infections

\section{Introduction}

Sarcoidosis was first described by Jonathan Hutchinson, an English physician, in 1877 [1]. This multi-systemic disease is characterized by the infiltration of various tissues by nonnecrotizing granulomas [2]. Although the mechanisms of granuloma formation are more and more clearly understood, there is currently no known cause of sarcoidosis (if there is any). Sarcoidosis can affect a wide variety of people, from the youngest to the oldest, regardless of ethnicity. Nevertheless, sarcoidosis is more common in young adults and classically starts earlier in men than women. In total, $70 \%$ of patients are aged between 25 and 40 years at presentation. A second peak of incidence is observed in women over 50 years old [3]. Its annual incidence is estimated between 2.3 and 11/100,000 while the estimated prevalence varies from 2 to 160 cases per 100,000 individuals. This large range for prevalence relies on the variability in diagnostic tools between studies as well as differences in the relative proportions of different ethnicities [4]. About two thirds of sarcoidosis patients experience a self-remitting disease without immunosuppressants, while the remaining third evolve through a chronic disease in which corticosteroids are the cornerstone of the treatment [4-6].

The diagnosis of sarcoidosis is still based on a set of arguments represented by three major criteria: clinical compatibility with the diagnosis of sarcoidosis, the absence of a differential diagnosis that is at least as likely, and the demonstration of epithelioid granulomas on histology [6]. Indeed, sarcoidosis can mimic other conditions which, if misdiagnosed as 
sarcoidosis, may result in a delay in diagnosis or treatment that is harmful to the patient especially in case of neoplastic or infectious diseases. These conditions include infections (e.g., tuberculosis, Bartonella spp.), neoplastic disorders (e.g., lymphomas), systemic diseases with granulomatosis (e.g., granulomatosis with polyangiitis (GPA), Crohn's disease [CD]), common variable immunodeficiency (CVID) and drug-induced (DI) sarcoid-like reactions (SLR). Before starting invasive investigations or initiating an immunosuppressive treatment, the clinician has to pay attention to these mimickers. Moreover, sarcoidosis patients are at increased risk of developing infections [7] and more specifically opportunistic infections which could mimic sarcoidosis or imitate a sarcoidosis flare [8]. The risk of developing solid neoplasia or hematological malignancies is increased in sarcoidosis patients [9]. This statement emphasizes the need for the clinician to pay attention to these differentials in that a delayed diagnosis can have negative consequences for the patient.

We hereby describe selected cases that came to our attention after referral to our internal medicine department for a suspected sarcoidosis diagnosis. In all cases, the physical examination, radiological examinations and the advanced microbiological or histological approaches allowed the identification of these differentials. We have chosen to focus on seven sarcoid mimickers and to summarize their main clinical features in light of their misleading or atypical presentation and the associated diagnostic approach.

\section{Materials and Methods}

This article is a series of original cases and adheres to the principles of the Declaration of Helsinki of 1964 and its latest amendments. The informed consent of all participants was obtained, and the study was approved by the Local Institutional Review Board. The case reports were chosen among consecutive patients referred to our internal medicine department. Each case report was selected as it was considered by the authors to be representative of the diagnostic issues faced by the clinician. This study received approval from the local ethics committee in February 2019 (No 19-31). In order to describe the updated diagnosis of these diseases, we conducted a review of the English and French medical literature on the Medline database, using the keywords "sarcoidosis", "mimickers", "misdiagnosed" and "differential diagnosis". We excluded articles written in languages other than English or French.

\section{Clinical Cases}

\subsection{Infectious Diseases \\ 3.1.1. Case Description}

A 70-year-old man was referred to our internal medicine department for suspected oral sarcoidosis. He had a past medical history of type 2 diabetes treated with insulin, and prostate cancer in remission treated with radical prostatectomy along with adjuvant radiation therapy. He reported a trip to India four months after the onset of symptoms, with no medical issues at the time.

He noticed the appearance of an ulceration around tooth 38 in June 2016. A first gingival biopsy was performed by his dentist three months later, finding giant-cell granuloma without necrosis. A second biopsy was performed in a maxillofacial surgery department, showing again a non-necrotizing giant-cell granuloma pattern. Neither sample was tested for mycobacteria (Ziehl Nielsen staining, culture or polymerase chain reaction [PCR]). Of note, a few days after returning from India (a trip the patient took after the onset of oral ulceration), he developed dry cough which led to further investigations. A thoracic CT scan showed interstitial lung disease with diffuse micronodules, retractive consolidations, and traction bronchiectasis. There was no mediastino-hilar adenopathy. This pattern was initially considered to be consistent with thoracic sarcoidosis. Oral corticosteroid therapy $40 \mathrm{mg}$ /day was then started, which improved the dry cough, but with significant corticosteroid dependence and corticosteroids side effects such as decompensation of his diabetes. The patient was then referred to our internal medicine department for further management of his atypical, presumed sarcoidosis. 
Detailed patient interview did not reveal any recent altered general condition nor extrarespiratory symptoms. A magnetic resonance imaging (MRI) of the jaw was performed and evidenced a left mandibular lesion extending to the cheek, with numerous satellite enlarged lymph nodes, including a necrotic one. Biological examinations revealed an inflammatory syndrome with an elevated C-reactive protein $(16.9 \mathrm{mg} / \mathrm{L})$, and a positive interferon-gamma release assay (TB GOLD TEST QUANTIFERON: 5.66). There was no elevation of angiotensin-converting enzyme levels. A bronchial fibroscopy was performed. The bronchial biopsy evidenced nothing except aspecific inflammation without granuloma.

Finally, the bronchoalveolar lavage fluid culture revealed the presence of Mycobacterium tuberculosis (Mtb). The search for $r p o B$ mutations was positive, indicating a rifampicin resistant Mtb strain. The complete sequencing of the strain revealed mutations in favor of additional resistance to ethambutol, pyrazinamide, and ethionamide, defining extensively drug-resistant tuberculosis. The Mtb PCR performed a posteriori on the 2 nd oral biopsy was positive, indicating that tuberculosis was contracted before the trip to India. New ear nose and throat (ENT) examination with laryngoscopy revealed a pharyngeal lesion extending to the epiglottis, in favor of laryngeal tuberculosis.

The patient was transferred to the infectious diseases department and a combined antibiotic therapy of linezolid, amikacin, levofloxacin, cycloserin, bedaquillin, and paraaminosalicylic acid was initiated. Linezolid was stopped after 6 months because of neurotoxicity, as was amikacin, given the positive evolution. Other antibiotics were maintained for a total treatment duration of 18 months. ENT lesions gradually disappeared and the control BALF culture at 2 months of treatment was sterile.

\subsubsection{Discussion}

Non-caseating giant cell granulomas are the histological hallmark of sarcoidosis. Unfortunately, these are not specific to any disease and many infectious disorders may present with granulomatous features (Table 1). Tuberculosis is one of the main differential diagnoses of sarcoidosis especially in case of lung and lymph node involvement. Tuberculosis is worldwide way more frequent than sarcoidosis in that in 2019, 10 million people were affected by tuberculosis across the world.

Table 1. Infectious differential diagnosis of sarcoidosis and their main organ involvement.

\begin{tabular}{|c|c|c|c|c|}
\hline Diagnostic Subset & Infectious Agent & Involved Organs & Specific Notes & References \\
\hline \multicolumn{5}{|l|}{ Bacteria } \\
\hline & Mycobacterium tuberculosis & $\begin{array}{l}\text { Lung, lymph nodes, eye, skin, liver, } \\
\text { arthritis }\end{array}$ & $x$ & {$[10]$} \\
\hline & $\begin{array}{l}\text { Mycobacterium avium complex } \\
\text { or other atypical mycobacteria }\end{array}$ & $\begin{array}{l}\text { Lung, lymph nodes, skin, eye, } \\
\text { digestive tract (M. bovis), liver }\end{array}$ & $\begin{array}{l}\text { M. bovis is associated with } \\
\text { digestive involvement. }\end{array}$ & {$[11,12]$} \\
\hline & Bacille de Calmette et Guérin & Lung, lymph nodes, disseminated & Intravesical for bladder cancer & {$[13]$} \\
\hline & Mycobacterium leprae & Skin, PNS, lymph nodes, eye, joint & $X$ & {$[14]$} \\
\hline & $\begin{array}{l}\text { Brucella spp. } \\
\text { (melitensis/abortus) }\end{array}$ & $\begin{array}{l}\text { Spleen, liver, bone marrow, lymph } \\
\text { nodes, arthritis }\end{array}$ & $x$ & {$[15]$} \\
\hline & Listeria monocytogenes & $\begin{array}{l}\text { Eye, heart, CNS, granulomatosis } \\
\text { infantiseptica in the newborn }\end{array}$ & $\begin{array}{l}\text { Granulomatosis infantiseptica in } \\
\text { infants }\end{array}$ & [16] \\
\hline & Salmonella spp. & $\begin{array}{l}\text { Mesenteric lymph nodes, liver, } \\
\text { spleen, bone marrow. NB: CGD } \\
\text { promotes Salmonella infections }\end{array}$ & $\begin{array}{l}\text { CGD promotes Salmonella } \\
\text { infections and infections with } \\
\text { other intracellular bacteria } \\
\text { (defective oxidative burst) }\end{array}$ & {$[17]$} \\
\hline & Nocardia spp. & Lung, brain, skin, liver & $\begin{array}{l}\text { Nocardiosis also occurs in } \\
\text { sarcoidosis patients }\end{array}$ & {$[18,19]$} \\
\hline & Francisella tularensis & Lymph nodes, eye, skin, heart, lung & $x$ & [20-22] \\
\hline & Tropheryma Whipplei & $\begin{array}{l}\text { Joints, CNS, eye, heart, liver, skin, } \\
\text { gut }\end{array}$ & $x$ & {$[23]$} \\
\hline & Bartonella spp. & $\begin{array}{l}\text { Liver, spleen, skin, lymph nodes, eye, } \\
\text { heart }\end{array}$ & $x$ & {$[24-27]$} \\
\hline
\end{tabular}


Table 1. Cont.

\begin{tabular}{|c|c|c|c|c|}
\hline Diagnostic Subset & Infectious Agent & Involved Organs & Specific Notes & References \\
\hline & Q fever (Coxiella burnetii) & $\begin{array}{l}\text { lung, liver, bone marrow, heart, } \\
\text { lymph nodes, arthritis }\end{array}$ & $\begin{array}{l}\text { Granulomas are associated with } \\
\text { acute forms, chronic courses of } \\
\text { Q fever are more often non } \\
\text { granulomatous. Characteristic } \\
\text { granuloma in Q fever is called } \\
\text { "doughnut granuloma". } \\
\text { Preferentially non necrotizing } \\
\text { granulomas. }\end{array}$ & {$[28,29]$} \\
\hline & Lyme disease & $\begin{array}{l}\text { Skin, joint, bone, eye, heart, } \\
\text { muscle }\end{array}$ & & [13] \\
\hline & Syphilis (Treponema pallidum) & $\begin{array}{l}\text { Skin, eye, lymph nodes, liver, } \\
\text { vascular and gummatous } \\
\text { syphilis }\end{array}$ & $\begin{array}{l}\text { Granuloma are especially found } \\
\text { in tertiary forms (gummatous } \\
\text { syphilis and proliferative } \\
\text { granuloma) }\end{array}$ & [30] \\
\hline & Actinomycosis & $\begin{array}{l}\text { Skin, lung, lymph nodes, CNS, } \\
\text { digestive tract, liver, pelvis }\end{array}$ & $\mathrm{x}$ & [31] \\
\hline & $\begin{array}{l}\text { Melioidosis (Burkholderia } \\
\text { pseudomallei) }\end{array}$ & $\begin{array}{l}\text { Lung, skin, joint, bone, CNS, } \\
\text { heart }\end{array}$ & $x$ & [32] \\
\hline & Yersinia spp. & Digestive tract, lymph nodes & $x$ & [33] \\
\hline & $\begin{array}{l}\text { Donovanosis }(K . \\
\text { granulomatosis) }\end{array}$ & Lymph nodes, genitals & $\begin{array}{l}\text { Context of unsafe sexual } \\
\text { practices }\end{array}$ & [34] \\
\hline & $\begin{array}{l}\text { Lymphogranuloma venereum } \\
\text { (C. trachomatis serovar L1-L3) }\end{array}$ & Lymph nodes, genitals, anus & $\begin{array}{l}\text { Context of unsafe sexual } \\
\text { practices }\end{array}$ & [35] \\
\hline \multicolumn{5}{|l|}{ Viruses } \\
\hline & CMV & Any organ & $x$ & {$[36,37]$} \\
\hline & EBV & Lung, skin, lymph nodes (LYG) & $x$ & [38] \\
\hline & HSV-1, HSV-2 and VZV & Skin, eye, CNS, lung, liver & $x$ & {$[39,40]$} \\
\hline & HIV & $\begin{array}{l}\text { Skin (granuloma annulare), any } \\
\text { organ (LYG) }\end{array}$ & $\begin{array}{l}\text { Other associated conditions } \\
\text { (mycobacteria, CMV, syphilis, } \\
\ldots \text { ) }\end{array}$ & [41-43] \\
\hline & HBV & Skin (granuloma annulare), liver & $x$ & {$[44,45]$} \\
\hline & $\mathrm{HCV}$ & Skin (granuloma annulare), liver & $\begin{array}{l}\text { Possible interferon-induced } \\
\text { granulomas }\end{array}$ & {$[46,47]$} \\
\hline & SARS-CoV2 & $\begin{array}{l}\text { Skin (granuloma annulare), } \\
\text { kidney }\end{array}$ & $x$ & {$[48-50]$} \\
\hline \multicolumn{5}{|l|}{ Parasites } \\
\hline & Toxoplasma gondii & CNS, lymph node, eye & $x$ & [13] \\
\hline & Schistosoma spp. & Digestive tract, pelvis, liver & $x$ & [51] \\
\hline & Leishmaniasis & $\begin{array}{l}\text { Skin, spleen, bone marrow, } \\
\text { lymph nodes }\end{array}$ & $x$ & [52] \\
\hline & Echinococcus spp. & Liver, lung & $x$ & [13] \\
\hline & Toxocarosis & Liver, lung, eye, CNS & $x$ & [13] \\
\hline & Cysticercosis & CNS, muscle, eye & $x$ & [53] \\
\hline \multicolumn{5}{|l|}{ Fungi } \\
\hline & Cryptococcosis & $\begin{array}{l}\text { CNS, skin, lymph nodes, lung, } \\
\text { joints }\end{array}$ & $\begin{array}{l}\text { Sarcoidosis patients may } \\
\text { develop cryptococcosis without } \\
\text { immunosuppression }\end{array}$ & [54] \\
\hline & Histoplasmosis & Lung, CNS, digestive tract & $x$ & {$[6,55]$} \\
\hline & Aspergillus spp. & Lung, skin, disseminated & $x$ & {$[6,56]$} \\
\hline & Blastomycosis & Lung, skin & $x$ & [6] \\
\hline & Pneumocystis jiroveci & Lung & $x$ & [57] \\
\hline
\end{tabular}

Abbreviations: CGD: chronic granulomatous disease, CNS: central nervous system, EBV: Epstein-Barr virus, HBV: hepatitis B virus, HCV: hepatitis $C$ virus, HIV: human immunodeficiency virus, HSV: herpes simplex virus, PNS: peripheral nervous system, SARS-CoV2: severe acute respiratory syndrome coronavirus type $2, \mathrm{VZV}$ : varicella zoster virus. 
Tuberculosis and sarcoidosis are hard to distinguish from each other since even extra pulmonary manifestations may be similar in both diseases (i.e., uveitis, digestive tract involvement, neurological involvement, peripheral lymphadenopathies, arthritis, hypodermitis). Several general and nonspecific clinical signs may be present in both diseases, including fever, weight loss, night sweats, malaise, and fatigue, as well as being born abroad in a country where tuberculosis is highly endemic and having been in contact with tuberculosis [58]. Of note, some of the patient's history features can be atypical for sarcoidosis, notably hemoptysis and centrolobular micronodules, cavitary lesions and unilateral adenopathy. In case of ocular involvement, occlusive vasculitis, serpiginous-like choroiditis, single choroidal granuloma and perivascular choroiditis patches are more consistent with tuberculosis whereas segmental and nodular vasculitis are more prone to revealing sarcoidosis [59]. ENT involvement is not rare in sarcoidosis patients but oral involvement (e.g., gingival and jugal involvement) is atypical and should raise the question of a differential diagnosis.

Various diagnostic tools are available for mycobacterial infections. Tuberculin skin tests can be falsely negative in sarcoidosis patients defining tuberculin anergy. Interferon gamma release assays (IGRAs) are valuable alternatives in this setting to diagnose latent tuberculous infections (LTBI). This type of test is not applicable to the diagnosis of active TB due to the non-neglectable amount of false negative results in active-TB patients [60].

Sputum microscopy searching for Mtb acid-fast bacilli and liquid phase cultures are the most widely used tests for tuberculosis diagnosis [61]. In recent decades, the advances of molecular genetics have allowed for an improvement in the detection of Mtb and antibiotics resistance of the strains. Several molecular detection tests for Mycobacterium tuberculosis relying on polymerase chain reaction are available. The Xpert MTB/RIF test is probably the most known of rapid molecular tests for tuberculosis diagnosis. Its principle is based on heminested PCR assay to amplify sequences from the rpoB genes with specific probes to target mutations within the rifampicin-resistance determining region [62]. The sensitivity and specificity of the test rely on several pre-test conditions including smear positivity, HIV status, sample site (e.g., pulmonary or extra pulmonary), age and endemic burden in the country [63].

Several studies found that search for genetic material from tuberculous and nontuberculous mycobacterial (M. paratuberculosis, M. avium) in tissues from sarcoidosis patients could be positive despite the absence of any infectious sign [64-66]. One assumes that several environmental triggers, including mycobacterial antigens, could promote the formation of granulomas in predisposed individuals. Moreover, several animal models of granuloma are induced through mycobacterial derived antigens (either from Mtb or non-tuberculous mycobacteria) [67].

Other infectious conditions can present as granulomatosis. When facing a diagnosis of granulomatosis, the first step is to assess which organ is affected to perform a correct differential diagnosis [13]. If granulomas are found within the liver, hepatitis C or B viruses must be ruled out. Fibrin-ring granulomas within the liver should prompt a search for $Q$ fever, cytomegalovirus (CMV) or Epstein-Barr Virus (EBV) [68]. When associated with eosinophil granulocytes, granulomas should invoke the diagnosis of schistosomiasis, especially in endemic regions [13]. In endemic areas, Histoplasma capsulatum can present with granulomatous lung disease along with bone marrow, liver, spleen and lymph node involvement while adrenal glands, skin and mucosal involvement are less frequent [69].

Thus, when facing an unexplained granulomatosis, infectious differential diagnoses should be ruled out (especially tuberculosis). Bacterial, fungal, viral and parasitological investigations should be performed, either systematically for tuberculosis or according to the patient's origin, previous trips in endemic areas or according to the specific organ involvement pattern (Table 1).

A careful histological examination is also a key point for an accurate diagnosis since some pathological features help to orientate a specific disease. Tuberculoid granuloma with central caseous necrosis helps to orientate mycobacterial infections, cryptococcosis, 
histoplasmosis and brucellosis, while suppurative or pyoepithelioid granulomas help to orientate bartonellosis, yersisniosis, chlamydiosis or tularemia [70]. Whipple's disease granulomas, as well as syphilitic granulomas, more frequently present with a sarcoid-like pattern. When histological examination reveals central necrosis, one should focus on the type of necrosis. Fibrinoid necrosis is different from caseous necrosis with an intense red color marking fibrin on hematoxylin eosin staining [71]. This pattern is associated with vascular damage more frequently linked to vasculitis either immune-mediated vasculitis (e.g., rheumatoid arthritis, ANCA associated-vasculitis [AAV]) or infectious vasculitis (e.g., rickettsiosis, syphilis).

\subsection{Neoplastic Disorders \\ 3.2.1. Case Description}

A 66-year-old male patient was admitted to our internal medicine department to explore mild asthenia, with a $2 \mathrm{~kg}$ weight loss, diffuse myalgia and persistent biological inflammatory syndrome (C reactive protein ranging from 100 and $220 \mathrm{mg} / \mathrm{L}$ ). His medical history included diffuse cardiovascular disease, duodenal ulcer and resected bladder polyps.

The symptoms had been present for two months. The physical examination was unremarkable. Chest X-ray and abdominal ultrasound were initially considered normal. Initial laboratory workup showed no cytopenia, no renal or hepatic dysfunction, no hypercalcemia, lactate dehydrogenase was slightly elevated (284 UI/L). Blood and urine cultures, Quantiferon, HIV, hepatitis B and C serology were negative. The Angiotensin conversion enzyme dosage was within the normal range (36.9 U/L). A Thoracic and abdominal CT found multiples mediastinal adenopathies (the largest in the Barety's space measuring $23 \mathrm{~mm}$ ), and cervical adenopathies, with several aspecific pulmonary micronodules. Since the first line investigations remained undiagnostic, a bone marrow aspiration was performed. The myelogram and blood clonality found no evidence of hemopathy. Broncho alveolar lavage fluid culture found no microbial agent, including Mycobacterium tuberculosis, but a lymphocytic alveolitis (90\%) with CD4/CD8 ratio of 1.27 .

The biopsy of a cervical adenopathy found pyoepithelioid inflammation, with partial necrosis and histiocytes, without giant cell. A broader infectious research was then realized: universal PCR, Tropheryma whipplei specific PCR and cultures on the adenopathy were negative. Yersinia spp., Bartonella spp., Francisella tularensis, Chlamydia spp. and syphilis serology were negative.

In case of occult infection with intracellular bacteria, a probabilistic treatment with doxycycline for one month was implemented without improvement, with the appearance of intense pruritus and bullous skin lesions located on the extremities. The clinical picture was suggestive of an inflammatory disease (enlarged lymph nodes, skin lesion, pruritus, persistent fever and inflammatory syndrome) and treatment with corticosteroids was discussed. However, new symptoms (mild fever, polyneuropathy) appeared before it could be started, which led to a second workup. A positron emission tomography (PET)-CT showed growing mediastinal adenopathies (largest measured at $32 \mathrm{~mm}$ ), which were hypermetabolic (standardized uptake value: 5). Electroneuromyography found diffuse axonal polyneuropathy, lumbar puncture (mild hyperproteinorachia $0.7 \mathrm{~g} / \mathrm{L}$, no cells, no neoplastic infiltration, no oligoclonal bands) and brain MRI was unremarkable. Finally, a biopsy of the mediastinal adenopathy found Hodgkin's disease of scleronodular subtype. The evolution was favorable after chemotherapy.

\subsubsection{Discussion}

Neoplasia are another of the great mimickers of sarcoidosis. In cancer patients, systemic granulomatosis and SLR associated with cancer can occur either before, during or after the onset of the neoplasia. These granulomatous disorders can occur in many conditions in cancer patients (i.e., related to opportunistic infections associated with 
cancer, systemic granulomatosis due to cancer treatment, especially checkpoint inhibitors or BRAF/MEK inhibitors) [9].

Apart from the increased risk of cancer in sarcoidosis patients, SLR to tumor cells can be encountered in various types of cancer, either in solid or hematological malignancies [72]. Some authors have suggested that satellite SLR to cancer could be the marker of an efficient immune response to tumoral cells and thus making it a marker of good prognosis [73-76]. Systemic granulomatosis in the context of cancer can also occur. Arish et al. described a series of 29 patients diagnosed with sarcoidosis in a context of preexisting cancer. Breast cancer and lymphoma were the most frequently observed cancer types. These patients presented features of systemic granulomatosis (lymphocytic alveolitis, mediastinal and hilar lymphadenopathies, endobronchial granulomas in histological examination) but most of them were strictly asymptomatic [77].

Our case illustrates the need both for the pathologist to examine the specimen carefully but also for the clinician to raise awareness of the search for a particular disease, and in particular Hodgkin's disease in the context of atypical granulomatosis. In our case, Hodgkin's disease was associated with an important inflammatory syndrome and a non-specific chest CT pattern for sarcoidosis. These atypical features lead to a second diagnostic workup allowing a correct diagnosis at the end. Interestingly, another atypical feature was the pyoepithelioid inflammation which is unusual in sarcoidosis. In a recent series of necrotizing granuloma-like Hodgkin's lymphomas (NGHL), Hou et al. identified 34 cases of NGHL in 1887 Hodgkin's lymphomas (2\%) over a period of 14 years in their tertiary center in China [78]. In their series, NGHL cases were compared with non-NGHL cases. The authors found that the NGHL subtype, although rare, is associated with a poorer prognosis. Interestingly, three cases of NGHL in this series were initially misdiagnosed as cat scratch disease.

Sarcoidosis patients have also an increased risk of neoplasia as compared with general population. In 1973, Brincker et al. described an increased risk of lymphoma in a cohort of 2544 sarcoidosis patients [79]. In 1986, the same team described the sarcoidosis-lymphoma syndrome (SLS), a condition in which sarcoidosis patients develop a lymphoproliferative disorder, mostly in their fourth decade, in a median time of 24 months after the diagnosis of sarcoidosis [80]. The most frequent subtype of lymphoma encountered in the first series of SLS from Brincker is Hodgkin's disease whereas Papanikolaou and Sharma evidenced that non-Hodgkin's lymphoma was more frequent than Hodgkin's lymphoma [9]. In this subgroup, patients are usually older and present B symptoms more frequently.

Another subtype of lymphoproliferative disease mimicking sarcoidosis is lymphomatoid granulomatosis (LYG). LYG is a lymphoproliferative EBV-associated clonal disorder usually presenting with lung, lymph nodes, central nervous system and skin involvement in immunocompromised patients [38]. The typical histological patterns is represented by the coexistence of granulomatous inflammatory features composed of atypical and EBV positive CD20 positive B cells along with lymphocytic vasculitis and a certain amount of necrosis [81]. Its aggressiveness potential varies widely, from that of a diffuse large cell B lymphoma to that of an indolent lymphoma. An aggressive lymphoma occurs in 7 to $47 \%$ of LYG cases and LYG sometimes shares aggressive features with lymphoma thus indicating the need for chemotherapy [82]. This example enhances the necessity of a full examination of all samples when facing an atypical granulomatosis (i.e., with deeply impaired general condition or primary corticosteroid resistance).

Finally, in hematological malignancies, a specific subtype of sarcoidosis called "donoracquired sarcoidosis" can occur. This represents the putative transmission of sarcoidosis from a bone marrow donor to its recipient [83-85]. Moreover, unregarding the donor medical history, bone marrow transplant recipients for hematological malignancies can develop sarcoidosis either in a context of allogenic [84,86,87] or autologous [88,89] stem cell transplant. 


\subsection{Inflammatory Disorders and Systemic Diseases}

\subsubsection{Case Description}

A 40-year-old female was admitted to the emergency department for one-month lasting abdominal symptoms consisting of severe abdominal pain which was relieved by diarrhea. She reported severe fatigue and a $5 \mathrm{~kg}$ weight loss. She had taken nonsteroidal anti-inflammatory drugs for a dental abscess seven days earlier. She had low grade fever $\left(38.4{ }^{\circ} \mathrm{C}\right)$. The patient had a history of iron deficiency anemia, a cesarean section and a flange digestive occlusion. On physical examination, the abdomen was tender throughout without hepatosplenomegaly or palpable lymph nodes. Otherwise, the physical examination was unremarkable.

Blood tests found microcytic anemia (Hemoglobin $(\mathrm{Hb}): 9 \mathrm{~g} / \mathrm{dL}$, mean corpuscular volume of $80 \mathrm{fl}$ ) with both iron and vitamin B12 deficiency (ferritin: $12 \mu \mathrm{g} / \mathrm{L}, \mathrm{B} 1293 \mathrm{pmol} / \mathrm{L}$ $(138-652 \mathrm{pmol} / \mathrm{L})$ ) and elevated levels of acute phase reactants (i.e., C-reactive protein (CRP): $45 \mathrm{mg} / \mathrm{L}$ ). Renal and liver function tests were both normal.

The gynecological examination with endo-vaginal ultrasound was normal. Chest Xray was also normal. The abdomino-pelvic $\mathrm{CT}$ scan showed ileitis associated with multiple mesenteric lymph nodes enlargement up to $12 \mathrm{~mm}$. Hepatosplenomegaly of $12 \mathrm{~cm}$ with multiple intraparenchymal hypodense nodules was also described. Neither pathogens including tuberculosis (culture and PCR [intestine samples]), toxoplasmosis (serology), histoplasmosis (serology) and leishmaniasis (serology and PCR), nor any autoantibodies were found except positive parietal cell antibodies. Serum electrophoresis was normal as was angiotensin converting enzyme dosage. The culture and parasitological examination of the stools were negative as were serological testings for HIV and syphilis. Fecal calprotectin was elevated at $1168 \mu \mathrm{g} / \mathrm{g}(\mathrm{N}<50 \mu \mathrm{g} / \mathrm{g})$. Bone marrow aspiration evidenced a normal richness without pathological infiltration but with mild signs of dysmyelopoiesis. There was no macrophagic overload, especially Gaucher cells.

The diagnostic work-up was completed with a splenic MRI that showed multiple solid splenic lesions (Figure 1). Gastroscopy and ileocolonoscopy showed a nippled appearance of the terminal ileum without any other notable abnormality. Histological examination of the digestive tract biopsies revealed an atrophic gastritis with intestinal metaplasia compatible with Biermer disease. A PET-CT was performed and showed hypermetabolism of the splenic nodules, ileum, mediastinal and right supra clavicular lymph nodes, as well as pulmonary micronodules (Figure 2). Pulmonary function tests showed normal respiratory volumes without ventilatory or diffusion disorder. Bronchoscopy showed a normal macroscopic aspect of the respiratory tract. Bronchoalveolar lavage fluid (BALF) analysis evidenced a lymphocytic alveolitis with an increased CD4/CD8 ratio (13.34, N: 0.6-5.50). Infectious samples were negative, especially the mycobacterial cultures. Histological examination of bronchial biopsies showed a non-caseating giant cell granuloma suggesting a diagnosis of sarcoidosis.

The clinical picture was initially suggestive of systemic sarcoidosis with diffuse mediastinal, supra- and subdiaphragmatic lymph node involvement, associated with a multinodular spleen and pulmonary parenchymal involvement with bilateral micro-nodules. A corticosteroid treatment at $0.7 \mathrm{mg} / \mathrm{kg}$ per day was started regarding the major splenic and lymph node involvement responsible for impaired general condition.

The patient was then referred to our department. Because of the initial presentation with abdominal pains and ileitis, persistent digestive disorders under corticosteroids, we considered the diagnosis of Crohn's disease (CD) and cobalamin deficiency related to ileum involvement. A capsule endoscopy was performed and revealed multiple ulcerated lesions of the small intestine with two large ulcerations of 30 to $50 \%$ progression. The diagnosis of $\mathrm{CD}$ was finally retained. Infliximab $5 \mathrm{mg} / \mathrm{kg}$ was started in association with the decrease of corticosteroid therapy which allowed the rapid improvement of the patient's general condition and digestive symptoms. 


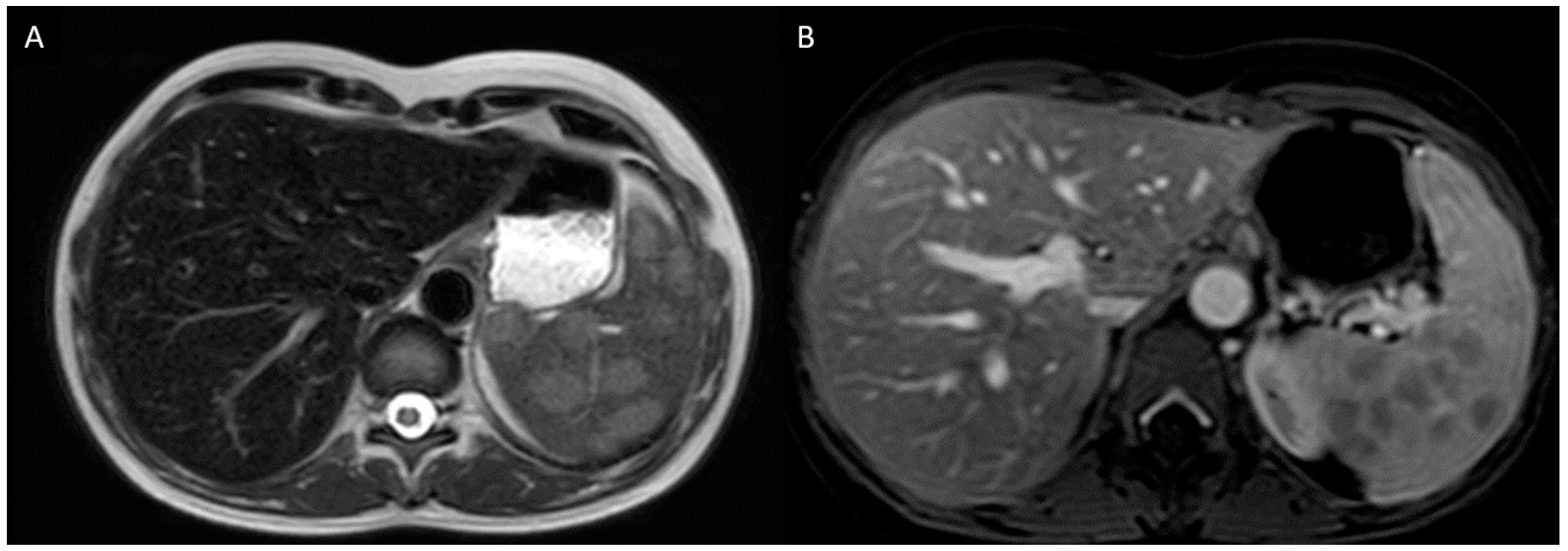

Figure 1. Axial abdominal MRI slices showing hyperintense splenic nodules on T2-weighted sequence (A) and hypointense signal on the early gadolinium-enhanced T1 acquisition (B).

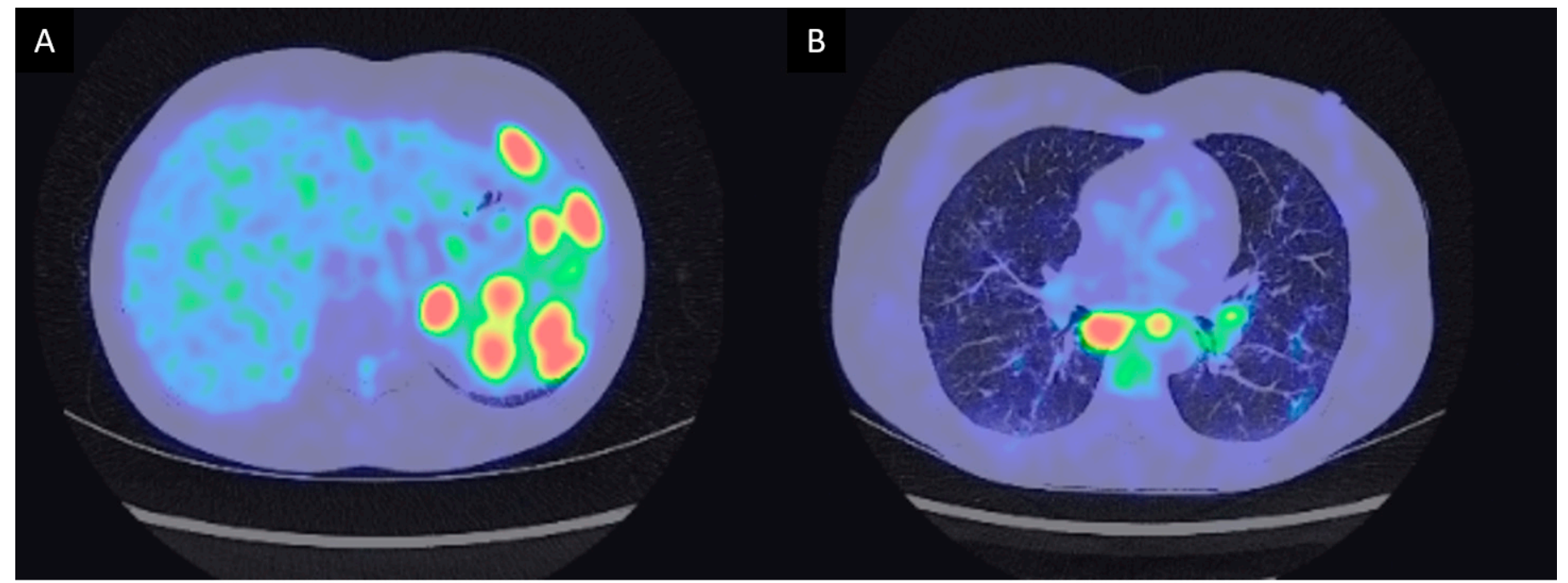

Figure 2. Axial PET-CT acquisitions showing increased metabolic activity in the spleen nodules (A) and in mediastinal lymph nodes (B).

\subsubsection{Discussion}

Several inflammatory or systemic disorders can mimic sarcoidosis or present with granulomas (Table 2). Granulomas can be found on histological samples in patients with anti-neutrophil cytoplasmic antibodies (ANCA)-associated vasculitides (AAV) either GPA or eosinophilic granulomatosis with polyangiitis (EGPA) and several presentations (e.g., crusting rhinitis, destructive sinusitis and orbital pseudotumor, myocarditis, arthritis as well as neurological manifestations) can be misdiagnosed as sarcoidosis [90].

Granulomatous lung diseases are a heterogeneous group of diseases including, in addition to sarcoidosis and granulomatous $\mathrm{AAV}$, both infectious diseases (e.g., mycobacterial or fungal infections) and non-infectious diseases (e.g., hypersensitivity pneumonitis, pneumoconiosis, nodular rheumatoid arthritis, Langerhans' cell histiocytosis, and bronchocentric granulomatosis) [103]. The positivity of ANCA with anti-PR3 specificity is a core feature for GPA diagnosis, since these antibodies are found in at least $90 \%$ of patients with systemic diseases and in $75-80 \%$ of patients with limited GPA without renal involvement, which was not the case in the patient described above [104]. 
Table 2. Auto inflammatory, autoimmune and systemic conditions mimicking sarcoidosis.

\begin{tabular}{|c|c|c|}
\hline & & Ref \\
\hline Crohn's disease & Digestive tract, eye, skin, joints, lung & \\
\hline $\begin{array}{l}\text { Granulomatosis with } \\
\text { polyangiitis }\end{array}$ & $\begin{array}{l}\text { Lung (consolidations without adenopathies), } \\
\text { kidney, sinonasal involvement, peripheral } \\
\text { nervous system, skin, eye, joints }\end{array}$ & [6] \\
\hline IgG4 related disease & $\begin{array}{l}\text { Lymph nodes, pancreas, large vessels, } \\
\text { exocrine glands, kidney }\end{array}$ & [91] \\
\hline Rheumatoid arthritis & Lung (rheumatoid nodule), joints & [6] \\
\hline Rosai Dorfman disease & Lymph nodes, skin, CNS & [92-94] \\
\hline Erdeim Chester disease & Pseudo granulomas (any organ) & [95] \\
\hline Amyloidosis & Any organ & {$[96,97]$} \\
\hline $\begin{array}{l}\text { Vogt Koyanagi Harada } \\
\text { disease }\end{array}$ & Eye, CNS, skin & [98] \\
\hline Blau syndrome & Eye, skin, joints, lymph nodes & [99] \\
\hline Giant cell arteritis & Vessels, skin & [100] \\
\hline Autoimmune hepatitis & \multirow{3}{*}{ Liver } & \multirow{3}{*}{ [6] } \\
\hline Primary biliary cholangitis & & \\
\hline Primary sclerosing cholangitis & & \\
\hline Kikuchi's disease & Lymph nodes & [101] \\
\hline Nieman Pick disease type C & IBD with granulomas & [102] \\
\hline
\end{tabular}

Necrotizing sarcoid granulomatosis (NSG) is a rare granulomatous disorder of the lung associated with vasculitis, which could be discussed as an alternative diagnosis in our patient. It is still controversial whether it is a discrete entity or a variant of nodular sarcoidosis. Its main features include (1) histological sarcoidosis-like granulomas, granulomatous vasculitis and a variable amount of necrosis, usually coagulative and caseous, (2) radiological multiple lung nodules without hilar lymphadenopathy, and (3) a benign clinical course. The clinical symptoms of NSG are often nonspecific (e.g., fever, chest pain, weight loss, cough and dyspnea) and the radiological findings vary widely (e.g., bilateral nodules and masses, cavitation, and pleural effusion). NSG does not usually affect extrapulmonary organs [105].

We report above the association of $\mathrm{CD}$ and sarcoidosis. Such an association is considered to be exceptional [106]. In an epidemiological study conducted in the United Kingdom, Rajoyira et al. reported that no significant association could be made between sarcoidosis and CD [107]. Contrarily, Halling et al. found an association between these two diseases, however exclusively in males with CD [108].

Digestive tract involvement is extremely rare in sarcoidosis, described in 0.1 to $1.6 \%$ of cases [109]. Even if the whole digestive tract can be involved, the stomach, and particularly the antrum, is the preferred location for digestive tract involvement in sarcoidosis [110]. The symptoms related to digestive tract involvement are usually non-specific and the diagnosis requires the presence of noncaseating granulomas within digestive tract histological samples and the exclusion other causes of granulomatous diseases including gastrointestinal-specific infections (Salmonella spp., Yersinia spp., Campylobacter spp., Helicobacter spp., Schistosoma spp., ... ), malignancies, vasculitides, foreign material reactions (talc, starch, barium, fecal material including pulse granuloma, pneumatosis) The main alternative diagnosis of granulomatous digestive disease is CD [110], which can also be associated with extra digestive features evocative of sarcoidosis such as arthritis, erythema nodosum and uveitis [109]. As compared with CD, digestive tract sarcoidosis occurs more frequently in African Americans and is more frequently associated with 
weight loss and ileum sparing. During the course of the disease, patients with digestive tract sarcoidosis classically do not require surgery and clinical digestive remission is more frequent.

Nucleotide-binding oligomerization domain-containing protein 2 (NOD2) polymorphisms in the leucine-rich repeat domain are positively associated with CD [111]. Of note, NOD2 mutations are present in Blau syndrome (BS), a differential diagnosis of early onset sarcoidosis [99].

Other diseases sharing the same impaired NOD2 pathway background may mimic sarcoidosis. We previously reported the case of a 19-year-old man referred to our department by ophthalmologists with suspicion of sarcoid uveitis [112]. He had a 15-year medical history of juvenile arthritis and bilateral panuveitis along with multifocal choroiditis. Given the presence of camptodactyly, the ophthalmological findings and the lack of intrathoracic adenopathies, the patient was diagnosed with BS. The complete sequencing the NOD2 gene evidenced a heterozygous gain-of-function missense mutation (Arg334Trp) which was already described in BS [113]. BS is transmitted as an autosomal dominant trait. It is also characterized by fever, skin rash (mainly non-confluent erythematous or millimetric pigmented papules) [114] and granulomatous inflammation of the involved organs [115]. Non-erosive arthritis is almost constant and mostly polyarticular, then oligoarticular and involves wrists, ankles, knees and proximal interphalangeal joints [116]. Rosé et al. reported expended manifestations (visceral, vascular) beyond the classic clinical trial in half of the patients [116]. Physicians should consider BS as a differential diagnosis of early onset sarcoidosis in children with unusual features such as camptodactyly and normal chest computed tomography (CT), even without familial history since BS can also be sporadic $[117,118]$.

\subsection{Drug-Implant- and Device-Induced Sarcoidosis}

\subsubsection{Case Description}

A 68-year-old patient had metastatic melanoma of an unknown primary tumor (with BRAF V600E mutation) diagnosed in 2008, with lung, adrenal, kidney, brain and bone metastases. He had been receiving vemurafenib as a fourth line treatment since May 2011, under a temporary authorization for use (French procedure allowing its use before its marketing authorization). This treatment resulted in rapid improvement of secondary lesions. 8 months after the introduction of vemurafenib, he presented with a purplish papular skin eruption at the elbow flexion sites, and on previous scars of the chest (Figure 3).

Skin biopsy revealed numerous epithelioid and gigantocellular granulomas, without caseous necrosis, suggesting cutaneous sarcoidosis. In the following months, he presented a non-granulomatous bilateral and recurrent anterior uveitis. He was therefore referred to our internal medicine department for suspected cutaneous and ocular sarcoidosis. Angiotensin conversion enzyme (ACE) levels were increased, and the remaining laboratory examinations were unremarkable. There was no parenchymal lung involvement on chest CT. The etiologic workup of this uveitis excluded other secondary causes of uveitis. Corticosteroids eyedrops were successfully introduced. However, the uveitis became chronic with multiple flares at topical corticosteroids withdrawal, and oral corticosteroids were therefore initiated in combination with hydroxychloroquine. While the uveitis and cutaneous granulomatosis were controlled under this treatment, the patient experienced a relapse of his metastatic melanoma. Unfortunately, he died of colonic perforation due to secondary localizations of his melanoma despite the use of several unsuccessful therapeutic lines. 


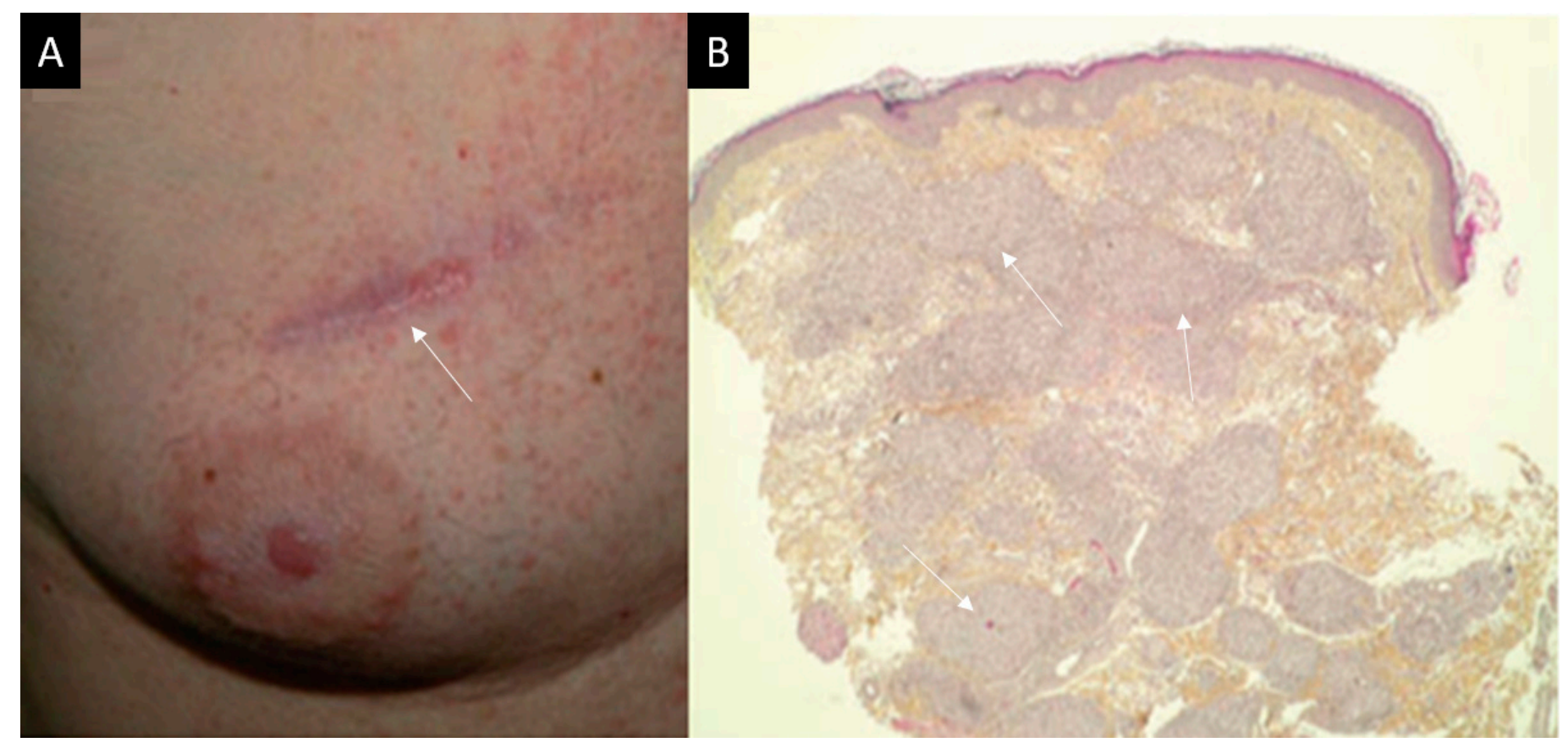

Figure 3. (A) Skin nodules on a scar of the anterior chest (white arrow). (B) Biopsy specimen of the skin lesion stained with haematoxylin-eosin-saffron showing numerous granulomas (white arrows); original magnification: $\times 200$.

\subsubsection{Discussion}

Drug-induced SLR can be defined as a "granulomatous reaction that is indistinguishable from sarcoidosis and occurs in temporal relationship with initiation of an offending drug" [119]. Many different therapeutics and microparticles were described to be responsible for SLR in the medical literature (Table 3). In addition to the reported case, we managed seven patients with DISLR due to interferon- $\alpha(n=1)$, etanercept $(n=2)$, adalimumab $(n=2)$, tocilizumab (TCZ) $(n=1)$ and immune checkpoint inhibitors $(n=1)$ over the 4 last years.

DISLR is well described during interferon therapy, (especially with interferon- $\alpha$ ), which is known to induce SLR along with lung involvement in up to $76 \%$ of patients with hepatitis $C$ and granulomatosis in a retrospective study [120]. In this study, RamosCasals et al. found that cutaneous granulomas were diagnosed in $60 \%$ of cases.

DISLR has also been described with tumor necrosis factor inhibitors (TNFi) and especially with the soluble receptor etanercept [119]. A literature review published last year found 107 DISLR cases, including 57 cases with etanercept, 27 cases with adalimumab, 21 cases with infliximab and 7 with other TNFi, treated during a mean period of 25.6 months (ranging from 1 to 132 months) [121]. Clinical symptoms were pulmonary (51\%) and cutaneous (33\%). In total, 14 patients had ocular involvement followed by salivary glands $(n=8)$, kidneys $(n=7)$, central nervous system $(n=5)$, and liver $(n=4)$ involvement. TNFi were discontinued, except in two cases. All but five cases showed clinical improvement after TNFi discontinuation with $(n=43)$ or without $(n=41)$ systemic corticosteroids, drug replacement $(n=5)$ or combined therapy $(n=10)$. The mechanisms evoked to explain the paradoxical granulomatosis development during anti-TNF therapy include increased susceptibility to infections and changes in cytokine and cellular environment.

A 47-year-old woman of African origin with a past medical history of rheumatoid arthritis (RA) for 14 years was referred to our department for a mediastinal histologically proven sarcoidosis. RA was treated with TCZ which was discontinued after the onset of the SLR. RA flared concomitantly with TCZ discontinuation. Thereafter, we introduced abatacept with good efficacy and safety, while hilar and mediastinal adenopathies regressed. While few cases showed the efficacy of anti-interleukin-6 (IL-6) or IL-6 receptor (IL-6R) 
agents in refractory sarcoidosis [3], new-onset sarcoidosis during TCZ treatment has been described in five case reports [137-141]. In three cases, there was what was presumed to be TCZ-induced sarcoidosis, observed during treatment for RA, at least one year after the start of the treatment. Theodosiou et al. and Del Giorno et al. recently reported TCZ-induced sarcoidosis in patients treated for giant cell arteritis, which occurred, respectively 12 and 8 months after TCZ initiation. In all these cases, the skin was involved as the main clinical feature, associated with bilateral hilar lymphadenopathy in three patients.

Table 3. Drug and device or microparticles-induced sarcoid-like reactions and their main organ involvements.

\begin{tabular}{|c|c|c|}
\hline & & Ref \\
\hline \multicolumn{3}{|l|}{ Drug-induced sarcoid-like reactions } \\
\hline Interferon (alpha or beta) & \multirow{8}{*}{ Lungs, lymph nodes, eyes } & {$[122]$} \\
\hline Ribavirin & & \\
\hline $\begin{array}{l}\text { Anti-TNF agents (etanercept } \\
>\text { adalimumab }>\text { infliximab }>\text { others) }\end{array}$ & & \\
\hline $\begin{array}{l}\text { Endothelin receptor antagonists } \\
\text { (ambrisentan }>\text { bosentan }>\text { macitentan) }\end{array}$ & & \\
\hline $\begin{array}{l}\text { Checkpoint inhibitors (PD1 and PDL1 } \\
\text { antagonists }>\text { CTLA } 4 \text { antagonists) }\end{array}$ & & \\
\hline BRAF inhibitors/MEK inhibitors & & \\
\hline Tocilizumab & & \\
\hline Brentuximab vedotin & & \\
\hline \multicolumn{3}{|l|}{ Microparticles-induced sarcoid-like reactions } \\
\hline Chronic beryllium disease & $\begin{array}{l}\text { Lung, bone marrow, liver, lymph nodes, } \\
\text { heart, skin }\end{array}$ & [123] \\
\hline Aluminium & Lung, digestive tract, injection sites & {$[124,125]$} \\
\hline Silicosis & Skin, lymph nodes & [126-129] \\
\hline Talc & Skin, liver, lung & [130-132] \\
\hline Coal & Bone marrow, local exposure & {$[133,134]$} \\
\hline Silicone & $\begin{array}{l}\text { Breast (local exposure), disseminated if } \\
\text { implant rupture }\end{array}$ & {$[135,136]$} \\
\hline
\end{tabular}

Abbreviations CTLA4: cytotoxic T-lymphocyte associated protein 4; PD1/PDL1: programmed cell death (ligand) 1; TNF: tumor necrosis factor.

Immune checkpoint inhibitors, such as anti-cytotoxic T-lymphocyte-associated protein4 (CTLA-4) antibodies (ipilimumab) and anti- programmed cell death protein 1 (PD1) (nivolumab, pembrolizumab) or anti-PDL1 (ligand) antibodies (atezolizumab, durvalumab, avelumab) can trigger DISLR [122]. BRAF and MEK inhibitors (dabrafenib, vemurafenib and trametinib, cobimetinib) were also associated with SLR in 37 patients in the World Health Organization database Vigibase. Like what is observed with other DISLR, immunotherapy generally triggers paucisymptomatic lung, skin and lymph nodes involvement (particularly mediastino hilar involvement). The onset of such manifestations varies between 1 and 22 months with a mean of 6 months after the initiation of treatment [142]. SLR can make one wrongly evoke cancer progression, and can include lung and liver nodules, localized or diffuse adenopathies and bone lesions [143]. Kim et al. recently reported a series of 32 patients with cancer who had a history of sarcoidosis and received immune checkpoint inhibitors [144]. Of these, only one patient had a sarcoidosis flare which required treatment. These findings suggest that most patients affected with cancer can receive immune checkpoint inhibitors without experiencing sarcoidosis flares, even if they have a past medical history of sarcoidosis. 
Apart from occupational or environmental diseases (Table 3) which present with granulomatous interstitial lung disease, SLR has been associated with inorganic particles, in a few reports, after joint replacement surgery [145] and after silicone breast implant placement [136]. These reactions are postulated to be due to an autoimmune inflammatory syndrome induced by adjuvants (ASIA) which existence was postulated by Shoenfeld et al. in 2011 [146]. The inability of the immune system to get rid of these antigens could promote a chronic inflammatory response which can enhance the antigen exposure to antigen-presenting cells [147]. This clinical entity should be differentiated from siliconoma which is exclusively associated with silica deposits.

We recently reported the case of a 44 year old woman of Caribbean origin referred to our department in a context of anterior bilateral granulomatous uveitis, interstitial lung disease, bilateral axillary lymphadenopathy and paresthesia along with neuropathic pain related to multineuritis [135]. She had a medical history of augmentation mammoplasty for esthetic purposes eight years ago, with a recent surgically treated breast implants rupture associated with siliconomas within breasts and enlarged axillary lymph nodes. Transbronchial, axillary lymph node and fibular nerve biopsies evidenced granulomatous inflammation. Further investigations with electron microscopy and energy dispersive Xray spectrometry were performed on transbronchial, lymphatic and nerve biopsies which revealed silicon particles within all the samples except nerve biopsy. We retained the final diagnosis of systemic granulomatosis linked to silicone spread and started corticosteroids with hydroxychloroquine, with good clinical efficacy. Overall, this observation suggests the interest of scanning electron microscopy and energy dispersive X-ray spectrometry for the diagnosis of implant and device-induced sarcoidosis.

\subsection{Primary Immune Deficiencies}

\subsubsection{Case Description}

A 53-year-old female patient of Portuguese origin was admitted to our internal medicine department in the context of a one-month history of right supra-clavicular adenopathy. She reported a $10 \mathrm{~kg}$ weight loss with asthenia for the past six months. She had a past medical history of meningitis, repeated cystitis and left cervicobrachial neuralgia. She also reported a history of stomach cancer in her mother and colon cancer in her brother.

The initial laboratory work-up showed isolated lymphopenia at $0.92 \mathrm{G} / \mathrm{L}$, a moderate inflammatory syndrome and a mild hypercalcemia $(2.7 \mathrm{mmol} / \mathrm{L})$. Serum protein electrophoresis showed normal gammaglobulin count $(7 \mathrm{~g} / \mathrm{L})$. Quantiferon was negative, angiotensin converting enzyme was increased to $119 \mathrm{IU} / \mathrm{L}$ and lysozyme to $59.2 \mathrm{IU} / \mathrm{L}$. Cervical ultrasonography and thoracic and abdominal CT scans showed a right supraclavicular adenomegaly $(25 \mathrm{~mm})$ with mediastinal and hilar nodes and a pulmonary infiltrative syndrome with bibasal reticulations, bronchiectasis and ground glass opacities. Lung function tests showed minimal distal bronchial obstruction. There was no restrictive ventilatory disorder and no decrease in alveolar-capillary diffusion. Bronchial fibroscopy showed macroscopic granulomatous infiltration with an increased CD4/CD8 ratio (5.74). Bronchial biopsies showed epithelioid and gigantocellular inflammation without caseous necrosis. Tuberculin skin test (TST) was negative. The supra-clavicular lymph node microbiopsy also showed epithelioid and gigantocellular granulomatous inflammation without caseous necrosis. Electrocardiography was normal with good left ventricular systolic and diastolic functions. The diagnosis of systemic sarcoidosis was made, and corticosteroids were started at $0.5 \mathrm{mg} / \mathrm{kg} /$ day for one month with a progressive withdrawal.

The initial clinical course was favorable with partial recovery of the initial weight and regression of enlarged lymph nodes. The thoracic CT showed the persistence of sequelae of fibrotic lesions. However, she subsequently developed hypercalcemia partly related to the discovery of a parathyroid adenoma, leading to the addition of hydroxychloroquine $400 \mathrm{mg}$ per day, a further increase in corticosteroids dosage and secondary with surgical management of the parathyroid adenoma. She also presented with right peripheral facial palsy with monoparesis of the right upper limb, which rapidly resolved under $1 \mathrm{mg} / \mathrm{kg} /$ day of 
corticosteroid. Neurological investigations (lumbar puncture and brain MRI) were normal without any sign suggestive of neurosarcoidosis. The corticosteroid therapy was stopped after one year of treatment and hydroxychloroquine was stopped one year later.

A new serum protein electrophoresis showed persistent hypogammaglobulinemia at $4 \mathrm{~g} / \mathrm{L}$ with $\mathrm{IgG}$ deficiency at $4.37 \mathrm{~g} / \mathrm{L}(7-16 \mathrm{~g} / \mathrm{L}), \mathrm{IgA}$ at $0.62 \mathrm{~g} / \mathrm{L}$ (0.7-4 g/L) and $\operatorname{IgM}$ at $0.41(0.4-3 \mathrm{~g} / \mathrm{L})$. Lymphocytes immunophenotyping confirmed a decrease in memory $\mathrm{B}$ cells (switched and non-switched) and an increase in naive B cells in favor of a common variable immunodeficiency (CVID) diagnosis. There was no transitional B cells expansion. There was a slight decrease of T cells $(359 / \mu \mathrm{L})$ along with low CD4 count $(205 / \mu \mathrm{L})$ under corticosteroids. Activated T cell phenotyping was unremarkable. The patient remains well under immunoglobulin substitution.

\subsubsection{Discussion}

The concept of immune deficiency has recently undergone major changes with advances in genetics. Thus, the group of primary immunodeficiencies, which is vast and heterogeneous, is now merged with that of inborn errors of innate immunity (IEIs). In 2021, there have been more than 450 single-gene innate errors of immunity underlying phenotypes encompassing as diverse manifestations as infections, malignancies, allergy, autoimmunity [148]. These phenotypes may be exclusive, but are most often overlapping, with immune deficiency being combined with, for example, autoimmune manifestations or lymphoproliferation [149]. The identification of genetic abnormalities, in addition to providing pathophysiological clues, also opens the way to the development of targeted specific treatments.

CVID, the most frequent primary immune deficiency in adults with an estimated prevalence worldwide between $1 / 10,000$ and 1/100,000 [150], is now linked to anomalies in more than 20 genes [148,149]. Of note, CVID has a familial aggregation in 5-25\% of the cases, and a single gene mutation is identified in less than $10 \%$ of patients [151]. In its original definition, CVID is an increased susceptibility to infections (particularly encapsulated bacteria) linked to a defective antibody production in the more global context of hypogammaglobulinemia. According to the European Society for Immuno deficiencies, CVID results from a decreased immunoglobulin (Ig) G level ( $<2$ standard deviation below the mean for age) associated with a drop in at least another Ig isotype (IgA or IgM) or in IgG subpopulations (such as IgG2 or IgG4). This also results in a decreased response to vaccination whether it consists of a $\mathrm{T}$ dependent or $\mathrm{T}$ independent antigen presentation.

Immunophenotyping may also be indicative of CVID when it shows a decrease in switched memory B cells and in whole memory B cells population (CD19+CD27+IgDIgM- and CD19+CD27+IgD+). During the diagnostic workup, the clinician should focus on ruling out secondary hypogammaglobulinemia (e.g., myeloma, chronic lymphocytic leukemia, cryoglobulin, Good's syndrome, nephrotic syndrome or exudative enteropathy, and drug-induced hypogammaglobulinemia).

A rarer form of combined immunodeficiency affecting older adults, the Late-Onset Combined Immunodeficiency (LOCID, 5-8\% of CVID cohorts) is characterized by CD4 lymphopenia (naive T cells) and an increased susceptibility to opportunistic infections [152].

In addition to being associated with increased risk of autoimmune manifestations (relative risk of autoimmune cytopenias >100), increased risk of cancer (lymphoma, gastric cancer), CVID predisposes to lymphoproliferation, either as lymphoid hyperplasia $(4-7 \%)$ or granulomatosis $(9-15 \%)$, which can mimic a full-blown sarcoidosis $[153,154]$. In other cases (2-6\%), lymphoproliferation is malignant thus the differential diagnosis with lymphoma may be difficult and requires (sometimes repeated and orientated/extensive) histological analysis.

Granulomatosis may precede or reveal the diagnosis of CVID. In other cases, the diagnostic criteria for CVID may be absent at the onset of the disease and lowered immunoglobulin levels may occur secondarily. It is therefore essential to perform serum protein electrophoresis before concluding the diagnosis of sarcoidosis. Sarcoidosis is 
associated with hypergammaglobulinemia in at least half cases $[155,156]$ and normal electrophoresis (or low borderline values but not below normal values) should alert the clinician. Immunoglobulin subclass assays and lymphocyte immunophenotyping will then be helpful.

Some clues may point to CVID rather than sarcoidosis, such as a familial aggregation (or consanguinity), past medical history of repeated infections, concurrent autoimmune manifestations, atypical presentation, predominantly extra-pulmonary involvement, diffuse and multi-organ involvement (especially involvement of the spleen), or lymphoid hyperplasia involving extra-pulmonary organs. In chest X-rays or computed tomography (CT) scans, CVID-associated pulmonary involvement (whether it is granulomatous lymphocytic interstitial lung disease or lymphocytic interstitial pneumonia) is often more severe, with a higher frequency of random nodules over micronodules (with a lesser perilymphatic distribution), more frequent halo signs, bronchiectasia and less frequent hilar adenopathies compared with sarcoidosis patients. Finally, the CD4/CD8 ratio in BALF seems to be lower in CVID than in sarcoidosis (mean, 1.6 vs. 5) [157].

The genetic characterization of a suspected PID is important since the characterization of certain subgroups of PIDs can be accessible to a specific treatment. Functional CTLA4 deficiency, whether due to CTLA4 haploinsufficiency, LRBA deficiency or DEF6 deficiency, may be suspected in cases with lymphoproliferation (38-73\%) and granulomatous disorders (17-45\%) associated with complex autoimmunity (mainly cytopenias) and inflammatory enteropathy. This spectrum of diseases is characterized by T-cell lymphopenia, low classswitched B cells and reduced CTLA4 expression on memory Tregs (usually performed with flow cytometry). In DEF6 deficiency, the T cell exhaustion that is normally present in CTLA4 and LRBA mutated patients is lacking [158]. Infections, including opportunistic ones, affect around $60 \%$ of patients [159]. The key to diagnosis is hypogammaglobulinemia, which is present in $50-84 \%$ of cases [159,160]. The detection of CTLA4 deficiencies is important because of its associated therapeutic implications since the addition of exogenous CTLA4-Ig (abatacept) can efficiently improve the patients' condition [160].

Moreover, chronic granulomatous disease (CGD), a primary immune disorder in which phagocytosis is impaired due to pathologic mutation of the NADPH, thus inducing an oxidative burst defect, can present with granulomatous features. Even if the X-linked phenotype of CGD is the best-known phenotype, autosomal recessive transmission can occur and as a consequence, the disease can be observed in males and females as well. Aspergillus spp. infections as well as Staphylococcus aureus, Klebsiella spp., Burkholderia cepacia, Serratia marcescens and Salmonella spp. infections are frequent and repeated infectious triggers with impaired phagocytic response leads to granuloma formation around persisting antigens or microorganisms [161,162].

Few other monogenic IEI harboring granulomatous features (either in or out of the CVID spectrum) have been described so far (Table 4). Granulomatous manifestations had already been described in TNFRSF13B, BAFF-R, B2M, XIAP, SH2D1A and hypomorphic RAG1/2 mutations [163,164]. PI3K pathway defects (activated PI3 kinase delta syndrome or APDS) had rarely been associated with granulomas. In all described APDS cases in cohorts, granulomas occurred only after BCG (bacillus Calmette et Guérin) vaccination. Of note, not every monogenic CVID phenotypes had been associated with granulomas. This enhances the complex correlation between genotypes and phenotypic classification of IEIs regarding granulomatous manifestations. Nevertheless, the clinician should keep in mind that relevant clinical signs should be looked for when facing granulomatosis such as dysmorphic features, recurrent infections, familial aggregation of cases and hypogammaglobulinemia (which is highly unusual in the course of sarcoidosis) in order to properly diagnose PID. 
Table 4. Primary immunodeficiencies with granulomatous features.

\begin{tabular}{|c|c|c|}
\hline & & Ref \\
\hline \multicolumn{3}{|l|}{ CVID } \\
\hline LRBA deficiency & \multirow{2}{*}{ GLILD } & \multirow{2}{*}{ [158] } \\
\hline CTLA4 haploinsufficiency & & \\
\hline \multicolumn{3}{|l|}{ Other primary immune deficiencies } \\
\hline Chronic granulomatous disease & Skin, lung, sinuses & [165] \\
\hline RAG1-2 deficiency & Skin, lung, sinuses (GPA-like) & [166] \\
\hline TAP1/2 and TAPBP deficiency & Skin & [167] \\
\hline PLAID (PLCG2) & Skin & {$[99,168]$} \\
\hline Ataxia Telangiectasia & Skin, joints, bones & [169] \\
\hline NAID & Digestive tract, joints, skin, eyes & [99] \\
\hline XLP1-2 & LYG & [170] \\
\hline Hermansky Pudlak syndrome & Digestive tract, skin & $\begin{array}{l}{[171,} \\
172]\end{array}$ \\
\hline CARD9 deficiency & Skin (dermatophytosis) & [173] \\
\hline XIAP deficiency & Lymph nodes, digestive tract & [102] \\
\hline \multicolumn{3}{|c|}{$\begin{array}{l}\text { Abbreviations: CARD9: Caspase recruitment domain-containing protein 9, CTLA4: cytotoxic T-lymphocyte } \\
\text { associated protein 4, CVID: common variable immunodeficiency, GLILD: granulomatous lymphocytic interstitial } \\
\text { lung disease, GPA: granulomatosis with polyangiitis, LRBA: LPS-responsive beige-like anchor protein, LYG } \\
\text { lymphomatoid granulomatosis, NAID: NOD associated autoinflammatory disorder, PLAID: PLCG2 auto in } \\
\text { flammatory disorder, RAG: recombinant activating gene, TAP: transporter for antigen presentation/BP: binding } \\
\text { protein, XIAP: X-linked inhibitor of apoptosis protein, XLP: X-linked lymphoproliferative disease. }\end{array}$} \\
\hline
\end{tabular}

Among the 26 patients seen in our department, the one described herein presented with mild hypogammaglobulinemia along with a past medical history of recurrent infections. The granulomatous disorder was mostly due to common variable immunodeficiency, and one should note that hypogammaglobulinemia in a context of sarcoidosis is highly unusual and must question the diagnosis of primary humoral immunodeficiency. This highlights the need for careful elimination of differential diagnoses at first visit, especially with serum protein electrophoresis and a meticulous patient interview.

\subsection{Opportunistic Infections}

\subsubsection{Case Description}

A 52-year-old man was referred to our internal medicine department for investigation of subacute dysarthria and gait disorders in the context of stage IV sarcoidosis in remission for 13 years. His history included cancer of the left kidney, obstructive sleep apnea, gout and post-traumatic blindness. His sarcoidosis was a mediastino pulmonary sarcoidosis considered cured under corticosteroids with calcified adenopathies and pulmonary fibrosis with traction bronchiectasis on the CT scan.

The clinical picture was that of a bilateral static and kinetic cerebellar syndrome predominantly on the left associated with dysarthria evolving for more than 3 months. There was also a left hemiparesis with progressive consciousness disorders and confusion. The rest of the clinical examination was unremarkable. Brain MRI performed at the outset revealed a left cerebellar mass that was not enhanced after gadolinium injection and appeared hypersignal on T2 FLAIR-weighted sequences (Figure 4). The initial biological workup showed no inflammatory syndrome and no alteration of the renal or hepatic balance. The blood count was also normal except for deep lymphopenia with a CD4 count of $167 / \mathrm{mm}^{3}$. HIV serology was negative. A first lumbar puncture was considered normal, without hypercellularity, hyperproteinorachia or hypoglycorrhachia. Bacterial and mycobacterial cultures were negative. Herpes PCR (herpes simplex 1, 2 and varicella zoster virus negative) as well as John Cunningham virus (JCV) PCR. There was no evidence of 
toxoplasmosis or cryptococcosis. At this stage, corticosteroids were introduced for the hypothesis of neurosarcoidosis, without improvement of the patient's condition. In this context of diagnostic impasse, a brain biopsy was performed. Histological examination showed diffuse inflammation of the white matter with foamy macrophages positive for Periodic Acid Shiff staining and lymphocytes. There was also astrocytic gliosis. The JCV PCR on brain biopsy came back positive as did the one performed on a second lumbar puncture making the diagnosis of progressive multifocal leukoencephalopathy clear.

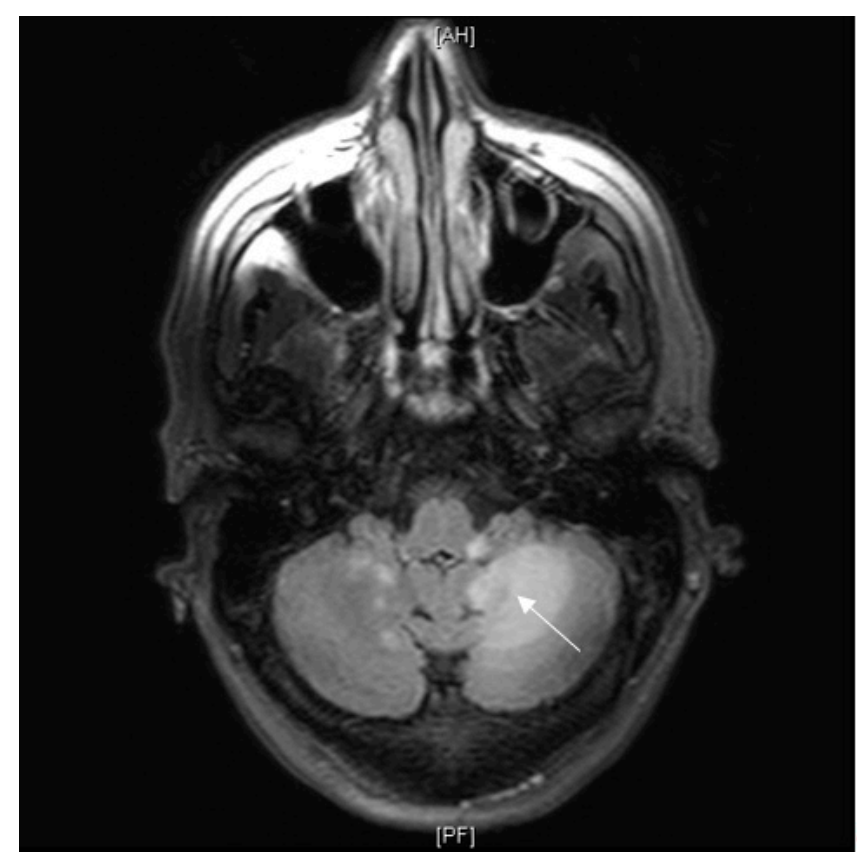

Figure 4. Brain magnetic resonance imaging from our patient with progressive multifocal leukoencephalopathy. Hyperintense left cerebellar mass on T2 FLAIR weighted sequences (arrow).

Treatment with mirtazapine and cidofovir was introduced with good tolerance and allowed a partial regression of the neurological disorders with a favorable evolution thereafter.

\subsubsection{Discussion}

Sarcoidosis patients may be at risk for opportunistic infections (OIs) and a few cases have been reported so far, even in untreated sarcoidosis patients. It is not clear how OIs in patients with sarcoidosis are different from other groups at risk [8]. Occult primary immunodeficiency, peripheral lymphopenia, deficit in macrophages functions and abnormal autophagy may represent valuable hypotheses to explain this increased risk of OIs in sarcoidosis patients [174]. Nevertheless, corticosteroids and immunosuppressants are the major risk factor for OIs and more widely severe infections in sarcoidosis patients $[7,54,175]$.

Tuberculosis and histoplasmosis have a predominant geographic distribution, with incidence being maximal in areas where these diseases are endemic. Several studies have reported an incidence of $0-10 \%$, but these studies were heterogeneous in terms of purpose, studied populations, sarcoidosis definition, and follow-up periods. One can consider that they should not be properly considered as opportunistic infections since they harbor confounding epidemiological risk factors, like geographic distribution.

All types of OIs have been reported in the setting of sarcoidosis whether they could be of bacterial, viral, parasitic or fungal origin. Cryptococcosis is the most frequently reported infection (59\%) followed by mycobacterial (either tuberculous or non-tuberculous) infections $(13 \%)$, nocardiosis $(11 \%)$, histoplasmosis $(9 \%)$, pneumocystosis $(9 \%)$, and aspergillosis (7\%) [8]. Severe OIs, such as progressive multifocal leukoencephalopathy due to JC virus, may also occur and challenge the differential diagnosis of neurosarcoidosis as illustrated by our case. In our case, sarcoidosis flare was suspected, and corticosteroids were introduced, 
without efficacy. OIs presenting with extrapulmonary features are often misdiagnosed as new localizations of sarcoidosis $[54,175]$. Chronic pulmonary aspergillosis and especially aspergillomas mostly develop on fibrocystic lungs [176] and patients with sarcoidosis and diffuse or cavitating lung disease present with the chronic pulmonary aspergillosis subtype which is the hallmark of infection on cavitating lung diseases [177].

There is currently no clear explanation for immunodepression in sarcoidosis patients. Even if clear risk factors had already been identified (corticosteroids, immunosuppressants), some patients can present without deep lymphopenia or iatrogenic immunosuppression. One could speculate that defective Treg expansion could be a possible explanation to inefficient immune regulation in sarcoidosis [178].

Of note, the autophagy/mTOR pathway which could be impaired in sarcoidosis also plays an essential role in innate immunity and defense against pathogens. For example, patients with HIV infection have an increased susceptibility to tuberculosis even if CD4+ T-cells are within the normal range. One of the suspected mechanisms to explain this is the autophagy dysregulation by HIV on different cell types [179].

Autophagy is crucial for the elimination of mycobacteria within infected cells and the evasion from the host's autophagy represents a major virulence factor for intracellular pathogens [180,181]. Non-tuberculous mycobacterial infections were also described during sarcoidosis and impaired macrophage's functions could be an interesting hypothesis to explain mycobacterial infections in sarcoidosis patients (e.g., defective autophagy, M2 phenotype, defective lysosomal or phagocytic pathways).

Thus, it is currently not possible to conclude an increased risk of OIs during sarcoidosis. In particular, it could not be proven that the CD4+ T-cells count influences the risk of OIs onset. Interestingly, patients who develop cryptococcosis during sarcoidosis' course were more prone to severe disease (i.e., cardiac and central nervous system sarcoidosis). Thus, many confounding factors can be hypothesized. Patients with severe sarcoidosis could be more prone to be treated with immunosuppressants or long course corticosteroids which increases the risk of infection $[7,182]$. Lymphopenia and more specifically CD4+ lymphopenia are also associated with active sarcoidosis and the deeper the lymphopenia, the more severe the sarcoidosis [183].

Finally, the occurrence of $\mathrm{OI}$ in a patient with sarcoidosis receiving immunosuppressants should prompt a reconsideration of the benefit/risk balance and consideration of a reduction in immunosuppression. Therapies that stimulate cellular immunity (interleukin2 , interleukin-7) have not proven their efficacy and could on the contrary induce sarcoidosis flare. For example, Guffroy et al. recently reported a case of sarcoidosis-associated PML whose OI improves under IL-7 at the cost of a major flare of sarcoidosis with the need for intensive care [184].

This case highlights the possibility of misdiagnosing an opportunistic infection during the course of sarcoidosis. These infections should not be confused with a sarcoidosis flare which would delay the correct diagnosis and correct treatment. The two most described opportunistic infections during sarcoidosis which are PML, and sarcoidosis can easily mimic neurosarcoidosis. Any atypical sign suggesting an alternative diagnosis (such as corticoresistant symptomatology like in our case description) should question a differential diagnosis and especially opportunistic infections, which are rare but deadly when the diagnosis is delayed, especially for PML [178].

\subsection{Neurosarcoidosis}

\subsubsection{Case Description}

A 30-year-old-female patient was admitted to the neurology department for a onemonth history of right hemiparesis associated with perioral paresthesias, gait instability and asthenia. The patient had no treatment other than oral contraception, no particular medical history other than 3 consecutive early miscarriages. She was of Turkish origin and arrived in France 12 years earlier. On admission, she described headaches and presented right arm monoparesis and ataxia with positive Romberg sign without cerebellar or vestibular 
syndrome. There was no sensory deficit nor cranial nerves involvement nor pyramidal irritation. The remaining physical examination was unremarkable.

The standard biological workup was normal (complete blood cells count, electrolytes, protein $C$ reactive, blood calcium, liver function tests, renal function). There was no vitamin deficiency (B1, B6, B9, B12). Serum protein electrophoresis showed polyclonal hypergammaglobulinemia. ACE was normal, serum lysozyme was increased at $24 \mathrm{mg} / \mathrm{L}$ $(\mathrm{N}<15 \mathrm{mg} / \mathrm{L})$. Viral serologies were negative for HIV, hepatitis B virus (HBV), hepatitis $\mathrm{C}$ virus (HCV), CMV and EBV. Varicella zoster virus (VZV) and toxoplasmosis serologies showed a long-standing immunity with the presence of IgG. The standard immunological work-up was within normal ranges: no anti-nuclear antibodies, ANCA, antiphospholipid antibodies, nor hypocomplementemia. The search for anti-aquaporin 4 antibodies was negative.

The lumbar puncture was normal without pleocytosis ( $<2$ nucleated elements, $<100$ red blood cells) or increased proteinorrachia. There was no intrathecal synthesis of immunoglobulins. Cerebrospinal fluid (CSF) culture was also negative (standard cultures and mycobacterial cultures). Cerebral Brain MRI showed confluent poorly limited intraaxial pontomesencephalic and cerebellar lesions in T2 and FLAIR hypersignal with low contrast enhancement after gadolinium injection without leptomeningitis (Figure 5).

The ophthalmological evaluation showed bilateral anterior uveitis and intermediate uveitis of the left eye. There were granulomatous retrodescemetic precipitates and vitreous opacities resembling the intermediate uveitis "ant eggs" pattern. The thoracoabdominopelvic CT scan was normal apart from homogeneous hepatomegaly. There was no pathologic lymph node enlargement nor pulmonary parenchymal involvement.

Despite normal minor salivary gland biopsy, medical history was first considered compatible with suggestive of neurosarcoidosis. The patient was treated with three methylprednisolone pulses at $1 \mathrm{~g} /$ day followed by a corticosteroid therapy at $1 \mathrm{mg} / \mathrm{kg}$ daily for 2 months before considering the decrease. Subsequently, the anti-myelin oligodendrocyte glycoprotein (MOG) antibody test came back positive. The evolution was favorable under corticotherapy with a regression of clinical and radiological lesions. Ophthalmologic examination was normal except for sequelae of uveitis. The final retained diagnostic was MOG antibody-associated disorder (MOGAD) anti-MOG associated inflammatory demyelinating disease. Currently, the patient is going well under prednisone $5 \mathrm{mg} /$ day.

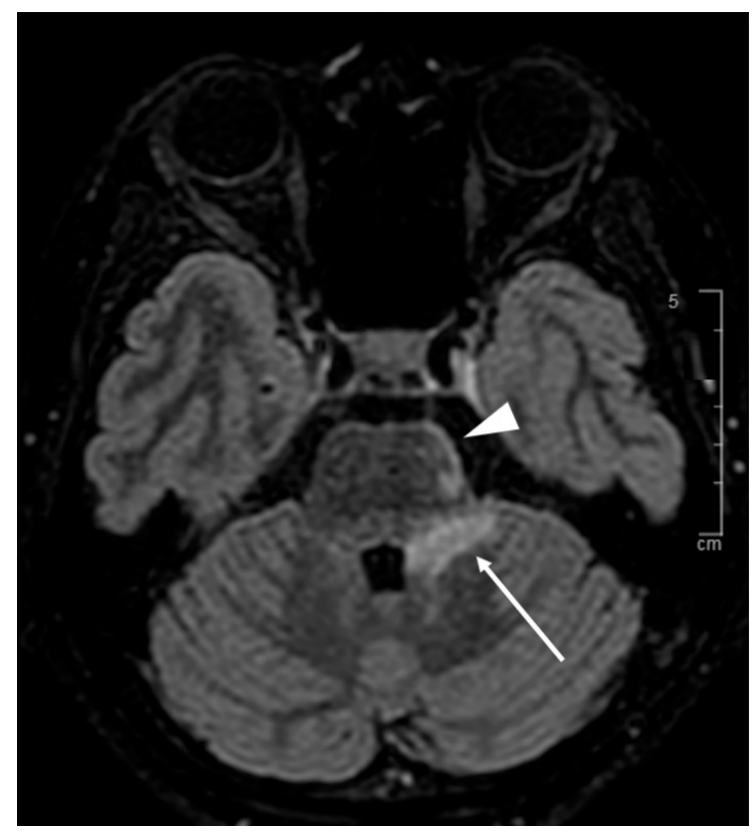

Figure 5. T2 FLAIR weighted sequence of brain magnetic resonance imaging evidencing pontomesencephalic (white arrow head) and right cerebellar inflammatory lesions. 


\subsubsection{Discussion}

MOGAD is usually associated with optic neuritis and/or myelitis [185] but several cases of uveitis have been recently described [186]. In our case, the appearance of the cerebellar peduncle lesion and the absence of intrathecal synthesis of immunoglobulins are highly suggestive of this diagnosis.

CNS demyelinating diseases among which multiple sclerosis (MS), Neuromyelitis Optica-Spectrum Disorders (NMO-SD) and MOGAD represent one of the most important differential diagnoses but many other neurological disorders share common features with neurosarcoidosis (Table 5) [187]. Infectious and neoplastic diseases, lymphoma in particular, must be ruled out as anti-inflammatory drugs or immunosuppressants would be ineffective even detrimental.

Neurosarcoidosis is one of the most difficult organ-site involvement to definitely diagnose, especially because biopsies are difficult to perform in routine practice and/or may represent a significant risk to the patient. Stern et al. recently provided actualized diagnostic criteria for neurosarcoidosis in three distinct categories: (1) definite if granuloma is histologically found on neurologic samples with consistent clinical presentation, (2) probable if granuloma is found on an extra neurologic sample and if the clinical presentation is consistent with sarcoidosis and (3) possible if no granuloma is found [187]. Neurosarcoidosis could affect any part of the nervous system. However, certain clinical and radiological features are particularly suggestive: cranial neuropathy (especially peripheral facial palsy and optic neuritis), leptomeningeal involvement with or without hydrocephalus, hypothalamic and pituitary abnormalities ... [188]. It is also important to note that 80 to $90 \%$ of patients with neurologic symptoms have, at the same time, ascertainable but often asymptomatic extra neural involvement [187]. In these situations, PET CT is a useful tool to assess both disease activity and potential biopsy sites [187,189]. Thus, isolated neurological damage should prompt the clinician to have a rigorous diagnostic approach to eliminate differential diagnoses. As such, CSF analysis could be very helpful. Neurosarcoidosis is typically associated with lymphocytic pleocytosis and increased CSF protein level. Hypoglycorachia is less frequent (around 15 to $20 \%$ of cases) but highly evocative. Immunoglobulins $\mathrm{G}$ oligoclonal bands are found in 20 to $50 \%$ of neurosarcoidosis patients versus for example more than $95 \%$ in MS [190,191]. Other CSF biomarkers like increased IL-6 and CD4/CD8 ratios may help to distinguish neurosarcoidosis from other neurological disorders, MS in particular [192]. As in other forms of sarcoidosis, corticoresistance (a situation when corticosteroids are unable to improve the patient's condition) should question for a differential diagnosis although it is more frequent in neurosarcoidosis compared with other extrapulmonary organ involvements. In about a quarter of patients, corticosteroid therapy alone is not sufficient or totally ineffective to allow remission [191]. In our case, even if the correct diagnosis was MOGAD, the corticosteroid treatment improved the patient's condition. In other cases, particularly in lymphoma cases, corticosteroids may improve the patient's condition to a certain extent but with a substantial risk of deleterious diagnostic delay. Consequently, neurological symptoms developing many years later in patients with already known extra neurologic sarcoidosis should first evoke an alternative diagnosis $[190,191]$.

Table 5. Main differential diagnoses of central nervous system sarcoidosis.

\begin{tabular}{lll}
\hline Diagnostic Subset & $\begin{array}{l}\text { Diagnostic Features Shared with } \\
\text { Neurosarcoidosis }\end{array}$ & References \\
\hline CNS inflammatory disorders & & \\
\hline Multiple sclerosis & WM lesions, short myelitis, ON & {$[192-195]$} \\
\hline NMO-SD and MOGAD & $\begin{array}{l}\text { ON especially if } \\
\text { bilateral/papilledema, LTEM }\end{array}$ & {$[192,196,197]$} \\
\hline
\end{tabular}


Table 5. Cont.

\begin{tabular}{|c|c|c|}
\hline Diagnostic Subset & $\begin{array}{l}\text { Diagnostic Features Shared with } \\
\text { Neurosarcoidosis }\end{array}$ & References \\
\hline PACNS & Stroke, leptomeningeal involvement & {$[192,198]$} \\
\hline CLIPPERS & $\begin{array}{l}\text { Response to steroids, punctate } \\
\text { enhancement }\end{array}$ & {$[192,199]$} \\
\hline Anti-GFAP associated disorders & $\begin{array}{l}\text { Myelitis, meningitis, papilledema, } \\
\text { punctate enhancement }\end{array}$ & {$[192,200]$} \\
\hline \multicolumn{3}{|l|}{ Infections } \\
\hline $\begin{array}{l}\text { Bacterial: tuberculosis (and other } \\
\text { mycobacteria),syphilis, Lyme disease, } \\
\text { Whipple disease, brucellosis }\end{array}$ & $\begin{array}{l}\text { Meningitis (hypoglycorrachia), } \\
\text { myelitis, ON }\end{array}$ & {$[10,192,201]$} \\
\hline $\begin{array}{l}\text { Fungal: cryptococcosis, } \\
\text { histoplasmosis ... }\end{array}$ & Meningitis (hypoglycorrachia) & {$[54,192,202]$} \\
\hline $\begin{array}{l}\text { Parasitic: toxoplasmosis, toxocarosis } \\
\ldots\end{array}$ & $\begin{array}{l}\text { Myelitis and ON for toxocarosis, } \\
\text { brain mass lesion(s) for toxoplasmosis }\end{array}$ & {$[192,203]$} \\
\hline \multicolumn{3}{|l|}{ Tumoral conditions } \\
\hline Lymphoma & Response to steroids, uveitis & {$[192,204]$} \\
\hline Lymphomatoid granulomatosis & Vasculitis, punctate enhancement & {$[192,205]$} \\
\hline Meningeal carcinomatosis & $\begin{array}{l}\text { Cranial nerve involvement, } \\
\text { leptomeningeal involvement, } \\
\text { hypoglycorrachia }\end{array}$ & [192] \\
\hline Metastases & Brain mass or meningeal lesions & [192] \\
\hline Meningioma & Pachymeningeal involvement & [192] \\
\hline $\begin{array}{l}\text { Histiocytic diseases: Langerhans cell } \\
\text { histiocytosis, Erdheim-Chester } \\
\text { disease and Rosai-Dorfman } \\
\text { syndrome }\end{array}$ & $\begin{array}{l}\text { Hypothalamic-pituitary involvement, } \\
\text { brain mass lesions }\end{array}$ & $\begin{array}{l}{[90,192,206,} \\
207]\end{array}$ \\
\hline Ependymoma & Spinal cord involvement & [192] \\
\hline Germinoma & $\begin{array}{l}\text { Hypothalamic-pituitary or optic } \\
\text { nerve involvement }\end{array}$ & [192] \\
\hline Glioma & Brain mass lesion(s) & [192] \\
\hline \multicolumn{3}{|l|}{ Systemic inflammatory disorders } \\
\hline Behcet's disease & Meningitis, uveitis, ON, myelitis & {$[192,195,208]$} \\
\hline GPA & $\begin{array}{l}\text { Pachymeningeal involvement, } \\
\text { vasculitis }\end{array}$ & {$[192,209]$} \\
\hline Sjögren syndrome & ON, myelitis & {$[192,195]$} \\
\hline SLE & Myelitis, vasculitis & [192] \\
\hline IgG4-related pachymeningitis & Pachymeningeal involvement & [187] \\
\hline \multicolumn{3}{|c|}{$\begin{array}{l}\text { Abbreviations: CLIPPERS: chronic lymphocytic inflammation with pontine perivascular enhancement respo } \\
\text { sive to steroids, CNS: central nervous system, GFAP: glial fibrillary acidic protein, GPA: granulomatosis wi } \\
\text { polyangiitis, LTEM: longitudinally transverse extensive myelitis, MOGAD: myelin oligodendrocyte glycoprote } \\
\text { antibody-associated disease, NMO-SD: Neuromyelitis Optica-Spectrum Disorders, ON: optic neuritis, PACN } \\
\text { Primary Angiitis of the CNS, SLE: systemic lupus erythematosus, WM: white matter. }\end{array}$} \\
\hline
\end{tabular}

\section{Discussion}

In our tertiary center, among 553 patients referred for a diagnosis of sarcoidosis in the last ten years, $26(4.7 \%)$ have been diagnosed with another condition. These cases, except those described above in the text, are depicted in Table 6. 
Table 6. Remaining cases with a wrong initial diagnosis of sarcoidosis in our tertiary center.

\begin{tabular}{|c|c|c|c|c|c|c|c|c|c|}
\hline Case & Sex & Age & Ethnicity & Clinical Features & $\begin{array}{l}\text { Atypical Features for } \\
\text { Sarcoidosis }\end{array}$ & $\begin{array}{l}\text { Time to Correct } \\
\text { Diagnosis }\end{array}$ & Diagnosis & Treatment & Outcome \\
\hline $1 *$ & M & 56 & Caucasian & $\begin{array}{l}\text { Hemoptysis, mediastinal } \\
\text { lymph nodes, multiple } \\
\text { parenchymal condensations } \\
\text { with excavations }\end{array}$ & $\begin{array}{c}\text { Hemoptysis, } \\
\text { excavated } \\
\text { parenchymal } \\
\text { condensation on chest } \\
\text { CT }\end{array}$ & 4 weeks & Tularemia & $\begin{array}{l}21 \text { days doxycyclin } \\
\text { course }\end{array}$ & Healing \\
\hline 2 & $\mathrm{~F}$ & 55 & Caucasian & $\begin{array}{l}\text { Isolated necrotic left sus } \\
\text { clavicular adenopathy with } \\
\text { hepatomegaly. Heterogenous } \\
\text { liver echogenicity }\end{array}$ & $\begin{array}{c}\text { Isolated } \\
\text { extramediastinal } \\
\text { lymph node without } \\
\text { parenchymal } \\
\text { involvement }\end{array}$ & 5 months & Cat scratch disease & $\begin{array}{l}1 \text { month course } \\
\text { doxycyclin }\end{array}$ & Healing \\
\hline 3 & M & 45 & Maghrebian & $\begin{array}{l}\text { Altered general condition with } \\
2 \mathrm{~kg} \text { weight loss. Hard, fixed } \\
\text { and painless left sus clavicular } \\
\text { and cervical adenopathies. } \\
\text { Sino nasal obstruction with } \\
\text { retropharyngeal adenopathies } \\
\text { with cavum mucosal } \\
\text { thickening }\end{array}$ & $\begin{array}{c}\text { Atypical } \\
\text { lymphadenopathies, } \\
\text { exclusive } \\
\text { extrathoracic multi } \\
\text { organ involvement. }\end{array}$ & 24 months & Hodgkin's lymphoma & $\begin{array}{l}\text { Chemotherapy } \\
\text { (ABVD, ICE) }\end{array}$ & $\begin{array}{c}\text { Currently } \\
\text { continuing } \\
\text { chemotherapy }\end{array}$ \\
\hline 4 & $\mathrm{~F}$ & 56 & Caucasian & $\begin{array}{c}\text { Cervical and axilar lymph } \\
\text { nodes. Cavum tumefaction. } \\
\text { Granulomas without atypical } \\
\text { features. Atypical CD30+ cells } \\
\text { on repeated lymph nodes } \\
\text { sampling. }\end{array}$ & $\begin{array}{l}\text { Cavum infiltration } \\
\text { and exclusive } \\
\text { extrathoracic lymph } \\
\text { nodes. }\end{array}$ & 72 months & $\begin{array}{c}\text { Biclonal lymphoma } \\
\text { (Hodgkin and Diffuse } \\
\text { large B cell lymphoma). } \\
\text { Hodgkin disease was } \\
\text { already present at disease } \\
\text { onset } 6 \text { years before } \\
\text { (second-look histological } \\
\text { examination). }\end{array}$ & $\begin{array}{l}\text { Chemotherapy } \\
\text { (R-CHOP 8x) }\end{array}$ & Healing \\
\hline
\end{tabular}


Table 6. Cont

\begin{tabular}{|c|c|c|c|c|c|c|c|c|c|}
\hline Case & Sex & Age & Ethnicity & Clinical Features & $\begin{array}{l}\text { Atypical Features for } \\
\text { Sarcoidosis }\end{array}$ & $\begin{array}{c}\text { Time to Correct } \\
\text { Diagnosis }\end{array}$ & Diagnosis & Treatment & Outcome \\
\hline 5 & M & 54 & Maghrebian & $\begin{array}{l}\text { Lower esophagus stenosis with } \\
\text { peri esophageal adenopathies } \\
\text { and dysphagia. Paratracheal } \\
\text { and subcarinal and antero } \\
\text { superior mediastinal lymph } \\
\text { nodes. Histological } \\
\text { examination concordant with } \\
\text { Piringer Kuchinka's } \\
\text { lymphadenitis. }\end{array}$ & $\begin{array}{l}\text { Compressive } \\
\text { phenomenon. No } \\
\text { hilar lymph nodes } \\
\text { with anterior } \\
\text { mediastinal lymph } \\
\text { nodes. }\end{array}$ & 40 months & $\begin{array}{l}\text { EBV positive Hodgkin's } \\
\text { lymphoma }\end{array}$ & ABVD 6 courses & Healing \\
\hline 6 & M & 75 & Hispanic & $\begin{array}{l}\text { Compressive right orbital } \\
\text { infiltrate. Isolated enlarged } \\
\text { lymph node of Barety area. }\end{array}$ & $\begin{array}{l}\text { Compressive } \\
\text { phenomenon. } \\
\text { Isolated mediastinal } \\
\text { lymph node without } \\
\text { hilar lymph node. }\end{array}$ & 17 months & $\begin{array}{l}\text { Right oribtal marginal } \\
\text { zone lymphoma } \\
\text { (previously improved by } \\
\text { local corticosteroids more } \\
\text { than a year before for } \\
\text { suspected scleritis). }\end{array}$ & Surgical resection. & Healing \\
\hline $7^{*}$ & $\mathrm{~F}$ & 63 & Caucasian & $\begin{array}{c}\text { Bilateral anterior and } \\
\text { intermediate uveitis. } \\
\text { Granuloma on MSGB. Gait } \\
\text { disturbance with multiple } \\
\text { supra tentorial demyelinating } \\
\text { lesions on FLAIR-weighted } \\
\text { sequences. }\end{array}$ & $\begin{array}{l}\text { Corticoresistant } \\
\text { uveitis and } \\
\text { neurological } \\
\text { involvement. }\end{array}$ & 3 years & Vitroretinal lymphoma. & $\begin{array}{c}\text { R-Metho AraC } \\
\text { chemotherapy } \\
\text { followed by ibrutinib } \\
\text { and R-VP16-Holoxan. }\end{array}$ & $\begin{array}{c}\text { The patient died } \\
3 \text { months after } \\
\text { the diagnosis } \\
\text { [204]. }\end{array}$ \\
\hline 8 & M & 53 & Caucasian & $\begin{array}{l}\text { Granulomatous kidney (renal } \\
\text { failure) and liver disease } \\
\text { (cirrhosis and portal } \\
\text { hypertension). Mesenteric and } \\
\text { cervical lymph nodes. } \\
\text { Monoclonal gammopathy. }\end{array}$ & $\begin{array}{c}\text { Exclusive } \\
\text { extrathoracic disease } \\
\text { with severe renal } \\
\text { involvement. }\end{array}$ & 47 months & Multiple myeloma & $\begin{array}{l}\text { Granulomatosis was } \\
\text { treated with } \\
\text { corticosteroids, } \\
\text { azathioprine and } \\
\text { mycophenolate } \\
\text { mofetil without clear } \\
\text { improvement. }\end{array}$ & $\begin{array}{l}\text { The patient died } \\
\text { a few days after } \\
\text { trans jugular } \\
\text { portal shunt } \\
\text { procedure. }\end{array}$ \\
\hline
\end{tabular}


Table 6. Cont

\begin{tabular}{|c|c|c|c|c|c|c|c|c|c|}
\hline Case & Sex & Age & Ethnicity & Clinical Features & $\begin{array}{l}\text { Atypical Features for } \\
\text { Sarcoidosis }\end{array}$ & $\begin{array}{l}\text { Time to Correct } \\
\text { Diagnosis }\end{array}$ & Diagnosis & Treatment & Outcome \\
\hline 9 & M & 50 & Caucasian & $\begin{array}{l}\text { Sus and subdiaphragmatic } \\
\text { lymph nodes in the course of } \\
\text { rheumatoid arthritis. }\end{array}$ & $\begin{array}{l}\text { Ground glass } \\
\text { opacities and } \\
\text { compressive lymph } \\
\text { nodes. }\end{array}$ & NA & $\begin{array}{c}\text { Sarcoid like reaction to ETN (at } \\
\text { introduction) }\end{array}$ & $\begin{array}{c}\text { ETN } \\
\text { withdrawal. } \\
\text { Monoclonal } \\
\text { antibody to } \\
\text { TNFa did not } \\
\text { provoke SLR } \\
\text { recurrence. } \\
\text { Rheumatoid } \\
\text { arthritis and } \\
\text { SLR improved } \\
\text { under } \\
\text { ustekinumab. }\end{array}$ & Healing \\
\hline $10^{*}$ & $\mathrm{~F}$ & 59 & Caucasian & $\begin{array}{l}\text { Bilateral anterior and } \\
\text { intermediate uveitis } \\
\text { mediastinal lymphadenopathy. } \\
\text { Previously treated with ADA } \\
\text { for rheumatoid arthritis. }\end{array}$ & No atypical features & Concomittant & SLR to ADA & $\begin{array}{l}\text { ADA } \\
\text { withdrawal, } \\
\text { Switch to } \\
\text { tofacitinib + } \\
\text { MTX + CS }\end{array}$ & $\begin{array}{c}\text { Free of } \\
\text { symptoms } \\
\text { under tofacitinib } \\
\text { and MTX. }\end{array}$ \\
\hline 11 & M & 80 & Caucasian & $\begin{array}{l}\text { Bilateral intermediate uveitis } \\
\text { and mediastinal } \\
\text { lymphadenopathies }\end{array}$ & No atypical features & Concomittant & SLR to ETN & Switch to ADA & $\begin{array}{c}\text { Free of } \\
\text { symptoms } \\
\text { under ADA. }\end{array}$ \\
\hline 12 & $\mathrm{~F}$ & 38 & Caucasian & $\begin{array}{c}\text { Uveitis, sarcoids. Lung } \\
\text { parenchymal involvement and } \\
\text { mediastino hilar } \\
\text { lymphadenopathies. } \\
\text { Melanoma with vemurafenib } \\
\text { and cobimetinib treatment. }\end{array}$ & No atypical features. & Concomittant & $\begin{array}{l}\text { SLR to vemurafenib and } \\
\text { cobimetinib ( } 9 \text { months } \\
\text { exposure) }\end{array}$ & CS & $\begin{array}{c}\text { The patient died } \\
\text { of her } \\
\text { melanoma } \\
\text { without severe } \\
\text { organ } \\
\text { involvement } \\
\text { due to SLR. CS } \\
\text { improved SLR. }\end{array}$ \\
\hline 13 & $\mathrm{~F}$ & 56 & Caucasian & $\begin{array}{l}\text { Bilateral panuveitis and } \\
\text { sarcoids. }\end{array}$ & No atypical features. & NA & $\begin{array}{l}\text { SLR to ADA (no exposure } \\
\text { data). }\end{array}$ & $\begin{array}{l}\text { Local CS and } \\
\text { ADA } \\
\text { withdrawal. }\end{array}$ & $\begin{array}{l}\text { Healing without } \\
\text { recurrence. }\end{array}$ \\
\hline
\end{tabular}


Table 6. Cont.

\begin{tabular}{|c|c|c|c|c|c|c|c|c|c|}
\hline Case & Sex & Age & Ethnicity & Clinical Features & $\begin{array}{l}\text { Atypical Features for } \\
\text { Sarcoidosis }\end{array}$ & $\begin{array}{l}\text { Time to Correct } \\
\text { Diagnosis }\end{array}$ & Diagnosis & Treatment & Outcome \\
\hline 14 & M & 59 & Caucasian & $\begin{array}{c}\text { Parenchymal lung } \\
\text { involvement, } \\
\text { hepatosplenomegaly, bone } \\
\text { marrow failure. Renal failure. }\end{array}$ & Febrile pancytopenia & Concomittant & $\begin{array}{l}\text { Mycobacterium genavense in a } \\
\text { previously known sarcoidosis. }\end{array}$ & $\begin{array}{l}\text { Ansatipine, } \\
\text { clarithromycin } \\
\text { and } \\
\text { moxifloxacin }\end{array}$ & Healing. \\
\hline 15 & M & 18 & Maghrebian & $\begin{array}{l}\text { Liver, spleen, lung and bone } \\
\text { marrow involvement. Diffusely } \\
\text { enlarged lymph nodes; }\end{array}$ & $\begin{array}{l}\text { Early onset (18 years } \\
\text { old), past medical } \\
\text { history of } \\
\text { opportunistic } \\
\text { infections } \\
\text { (actinomycosis) and } \\
\text { hypogammaglobu- } \\
\text { linemia }\end{array}$ & 180 months & LOCID & CS and IVIg & $\begin{array}{c}\text { Stable } \\
\text { pulmonary } \\
\text { function under } \\
\text { CS. No infection } \\
\text { under IVIg. }\end{array}$ \\
\hline 16 & $\mathrm{~F}$ & 37 & Caucasian & $\begin{array}{l}\text { Hypercalcemia, parenchymal } \\
\text { lung involvement with } \\
\text { mediastino hilar lymph nodes. } \\
\text { Skin granulomas. }\end{array}$ & $\begin{array}{l}\text { Repeated pulmonary } \\
\text { infections and } \\
\text { hypogammaglobu- } \\
\text { linemia. }\end{array}$ & 264 months & CVID-RGD & CS & $\begin{array}{l}\text { Healing. } \\
\text { The patient } \\
\text { remained free } \\
\text { from infections } \\
\text { under IVIg. }\end{array}$ \\
\hline
\end{tabular}

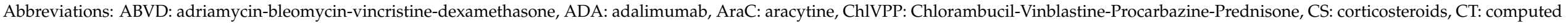

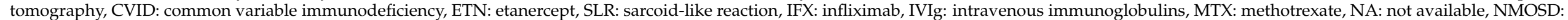

neuromyelitis optica spectrum disorder, RGD: related granulomatous disorder, R-CHOP: rituximab-cyclophosphamide-hydroxydoxorubicin-oncovin (vincristine)-prednisone, ${ }^{*}$ already published cases. 
Alternative diagnoses to granulomatous disorders mimicking sarcoidosis can be separated into seven different groups: (1) infectious disorders (e.g., tuberculosis, cat scratch disease, Whipple's disease), (2) neoplastic disorders (e.g., Hodgkin's lymphoma, germinoma), (3) iatrogenic SLR (e.g., SLR due to immune checkpoint blockade, BRAF/MEK inhibitors), (4) device or microparticle-induced granulomatous reactions (e.g., chronic beryllium disease, talc pneumonia, silicosis), (5) primary immunodeficiencies with granulomatous features (e.g., CVID, ataxia telangiectasia), (6) systemic disorders with granulomatous features (e.g., AAV, Blau syndrome, Rosai-Dorfman disease) and (7) some organ specific entities (e.g., hypersensitivity pneumonitis, granuloma annulare, Langerhans cell histiocytosis).

Most of the time, atypical features at diagnosis may help the clinician to distinguish sarcoidosis from its mimickers. Some clinical features are very atypical in a presumed sarcoidosis such as an unusual age at onset (before 25 and after 45 years old except for women for whom a second peak of incidence is noted after 50 years old), impaired general conditions, high fever (can be seen in Löfgren's syndrome, Heerfordt's syndrome, hepatic or renal sarcoidosis) clubbing, crackles at auscultation, hemoptysis or acute or subacute dyspnea (especially in the absence of lung fibrosis) [210]. Other organ involvements can be atypical too. For example, digestive tract involvement, isolated ileal involvement is exceptional and must suggest an alternative diagnosis (as we have discussed it for our patient). Corticoresistance is not a classic feature of sarcoidosis and should raise the question of a differential diagnosis (or more simply as a lack of compliance) [3].

In our literature review (Supplementary Table S1), corticoresistance was present in $60.2 \%$ of the cases. In this review, patients with Whipple's disease were more prone to present with corticoresistant disease $(p=0.02)$ as well as patients with mycobacterial infections $(p=0.02)$ or primary immunodeficiencies $(p=0.003)$. Exclusive extrathoracic involvement was also more frequently associated with microparticle-driven granulomatosis $(p=0.048)$. Interestingly, patients with infections, solid neoplasia or lymphoma were more prone to heal compared with others $(p<0.05)$. One could assume that this is due to the improvement of therapeutics against infectious agents or neoplasia over the years. To our knowledge, only limited data are available in the medical literature on how medical history, physical examination, laboratory, imaging and pathological investigations can be useful to make the correct diagnosis when facing a sarcoidosis mimicker. The American Thoracic Society recently published an official clinical practice guideline in which a panel of experts discussed and summarized evidence-based diagnostic management of sarcoidosis. Many diseases or pathological conditions may mimic sarcoidosis (Tables 1-6).

The clinician must be aware of red flags that may suggest a differential diagnosis whether they would be clinical (as discussed above), radiological (e.g., unilateral hilar lymphadenopathy (3-5\% of patients) or exclusive mediastinal lymphadenopathy without hilar lymph node enlargement, compressive lymphadenopathy, anterior mediastinal lymphadenopathy, miliary nodules, ground glass opacities, pleural involvement and bulky or cavitary mass (4\%)), biological (e.g., hypogammaglobulinaemia) or histological (extensive or dirty necrosis, palisading granulomas) [6,211-213]. Atypical radiological manifestations are of utmost importance. Generally speaking, these atypical presentations should encourage, as illustrated in our exemplary cases, the clinician to pay attention to other causes, including lymphoma, infectious granulomatosis (e.g., tuberculosis, leprosy, syphilis, bartonellosis, brucellosis, Q fever and Whipple's disease) and common variable immunodeficiency. Drug-related SLR and device or microparticle-induced granulomatous reactions are more easily diagnosed with medical history.

As shown above, the occurrence during the follow-up of atypical organ involvement (e.g., peritoneal or gut involvement) or new organ involvement in a previously controlled sarcoidosis, and refractory disease which is defined as a disease in which a second-line treatment is not sufficient to achieve satisfying disease control or satisfying CS tapering, in a patient with previously known sarcoidosis, must lead to histological confirmation to rule out opportunistic infection or neoplasia and especially lymphoma [3]. Of note, 
worsening of symptoms under corticosteroids is highly suspicious and should raise the question of a differential diagnosis of infection or neoplasia. When facing suspicion of neurosarcoidosis, PET CT can be useful to determine either CNS inflammation and/or extra neurologic biopsy sites with active sarcoidosis features [214]. Moreover, combination of F18 fluorothymidine and F18-FDG PET CT can be useful to distinguish neoplastic disorders from sarcoidosis [215].

Accordingly, all these unusual circumstances should question the accountability of sarcoidosis and lead the clinician to repeat histologic samples and microbiological analyses. Recent advances brought by translational research provided interesting tools to help the clinician distinguish new entities by making correlations between phenotypes and genotypes. The most striking example concerns the inborn errors of innate immunity. Recent advances in omics techniques especially genomics (whole exome, next generation sequencing, genome wide association studies) allowed a better characterization of primary immunodeficiencies [149]. The Genomic Research in Alpha-1 Antitrypsin Deficiency and Sarcoidosis (GRADS) propose to analyze transcriptome and microbiome data from sarcoidosis patients in order to identify novel biomarkers [216]. In a similar manner, omics techniques have provided interesting diagnostic tools to ease the identification and characterization of mycobacteria, especially matrix-assisted laser desorption ionizationtime of flight (MALDI-TOF), mass spectrometry and nucleic acid amplification tests [217].

\section{Conclusions}

Sarcoidosis, being a systemic disease of unknown etiology, can be a real diagnostic challenge. A careful clinical examination along with a rigorous diagnostic approach and an orientated examination of histological samples is of utmost importance in order to assess differential diagnoses. The clinician should be aware of such differentials when facing a granulomatous disorder, especially in case of atypical features for sarcoidosis. The diagnosis of sarcoidosis is based on the elimination of differential diagnoses which makes the diagnostic process all the more important, both for short- and long-term prognosis of the patient.

Supplementary Materials: The following are available online at https:/ /www.mdpi.com/article/10 .3390/diagnostics11071240/s1, Table S1: Cases misdiagnosed as sarcoidosis in medical literature.

Author Contributions: Conceptualization, T.E.J. and P.S.; methodology, T.E.J. and P.S.; software, RStudio analysis (v1.3.1093) T.E.J.; formal analysis, T.E.J.; writing-original draft preparation, T.E.J., P.S., Y.J., A.B., G.R.-C., E.W. and G.A.; writing-review and editing, T.E.J., P.S., Y.J., M.G.-V.; supervision, P.S. All authors have read and agreed to the published version of the manuscript.

Funding: This research received no external funding.

Institutional Review Board Statement: This study received the approval from the local ethics committee in February 2019 (No 19-31).

Informed Consent Statement: Informed consent was obtained from all subjects involved in the study.

Data Availability Statement: The dataset used for statistical analysis is cited as Table S1.

Conflicts of Interest: The authors declare no conflict of interest regarding this manuscript.

\section{References}

1. Hutchinson, J. Illustrations of Clinical Surgery; Churchill: London, UK; p. 42.

2. Valeyre, D.; Prasse, A.; Nunes, H.; Uzunhan, Y.; Brillet, P.-Y.; Müller-Quernheim, J. Sarcoidosis. Lancet 2014, $383,1155-1167$. [CrossRef]

3. El Jammal, T.; Jamilloux, Y.; Gerfaud-Valentin, M.; Valeyre, D.; Sève, P. Refractory Sarcoidosis: A Review. TCRM 2020, 16, 323-345. [CrossRef]

4. Arkema, E.V.; Cozier, Y.C. Epidemiology of Sarcoidosis: Current Findings and Future Directions. Ther. Adv. Chronic Dis. 2018, 9, 227-240. [CrossRef]

5. Hunninghake, G.; Costabel, U. Statement on Sarcoidosis. Am. J. Respir. Crit. Care Med. 1999, 160, 20. [CrossRef] 
6. Crouser, E.D.; Maier, L.A.; Wilson, K.C.; Bonham, C.A.; Morgenthau, A.S.; Patterson, K.C.; Abston, E.; Bernstein, R.C.; Blankstein, R.; Chen, E.S.; et al. Diagnosis and Detection of Sarcoidosis. An Official American Thoracic Society Clinical Practice Guideline. Am. J. Respir. Crit. Care Med. 2020, 201, e26-e51. [CrossRef]

7. Duréault, A.; Chapelon, C.; Biard, L.; Domont, F.; Savey, L.; Bodaghi, B.; Pourcher, V.; Rigon, M.R.; Cacoub, P.; Saadoun, D. Severe Infections in Sarcoidosis: Incidence, Predictors and Long-Term Outcome in a Cohort of 585 Patients. Medicine 2017, 96, e8846. [CrossRef] [PubMed]

8. Jamilloux, Y.; Valeyre, D.; Lortholary, O.; Bernard, C.; Kerever, S.; Lelievre, L.; Neel, A.; Broussolle, C.; Seve, P. The Spectrum of Opportunistic Diseases Complicating Sarcoidosis. Autoimmun. Rev. 2015, 14, 64-74. [CrossRef]

9. El Jammal, T.; Pavic, M.; Gerfaud-Valentin, M.; Jamilloux, Y.; Seve, P. Sarcoidosis and Cancer: A Complex Relationship. Front. Med. 2020. Accepted for publication. [CrossRef]

10. Gupta, D.; Agarwal, R.; Aggarwal, A.N.; Jindal, S.K. Sarcoidosis and Tuberculosis: The Same Disease with Different Manifestations or Similar Manifestations of Different Disorders. Curr. Opin. Pulm. Med. 2012, 18, 506-516. [CrossRef]

11. Gopalaswamy, R.; Shanmugam, S.; Mondal, R.; Subbian, S. Of Tuberculosis and Non-Tuberculous Mycobacterial Infections-A Comparative Analysis of Epidemiology, Diagnosis and Treatment. J. Biomed. Sci. 2020, 27, 74. [CrossRef] [PubMed]

12. Kaushik, J.; Jain, V.K.; Parihar, J.K.S.; Dhar, S.; Agarwal, S. Leprosy Presenting with Iridocyclitis: A Diagnostic Dilemma. J. Ophthalmic Vis. Res. 2017, 12, 437-439. [CrossRef]

13. Gousseff, M.; Mechaï, F.; Lecuit, M.; Lortholary, O. Les granulomatoses systémiques d'origine infectieuse. Rev. Méd. Interne 2008, 29, 15-27. [CrossRef]

14. White, C.; Franco-Paredes, C. Leprosy in the 21st Century. Clin. Microbiol. Rev. 2015, 28, 80-94. [CrossRef]

15. Franco, M.P.; Mulder, M.; Gilman, R.H.; Smits, H.L. Human Brucellosis. Lancet Infect. Dis 2007, 7, 775-786. [CrossRef]

16. Gellin, B.G. Listeriosis. JAMA 1989, 261, 1313. [CrossRef]

17. Mert, A.; Tabak, F.; Ozaras, R.; Ozturk, R.; Aki, H.; Aktuglu, Y. Typhoid Fever as a Rare Cause of Hepatic, Splenic, and Bone Marrow Granulomas. Intern. Med. 2004, 43, 436-439. [CrossRef]

18. Singh, A.; Chhina, D.; Soni, R.; Kakkar, C.; Sidhu, U. Clinical Spectrum and Outcome of Pulmonary Nocardiosis: 5-Year Experience. Lung India 2016, 33, 398. [CrossRef] [PubMed]

19. Rodríguez-Gutiérrez, G.; Toussaint, S.; Hernández-Castro, R.; del Carmen Sánchez-León, M.; Arenas, R. Nocardia brasiliensis Infection: An Emergent Suppurative Granuloma after Mesotherapy. Int J. Derm. 2014, 53, 888-890. [CrossRef]

20. Terrada, C.; Azza, S.; Bodaghi, B.; Le Hoang, P.; Drancourt, M. Rabbit Hunter Uveitis: Case Report of Tularemia Uveitis. BMC Ophthalmol. 2016, 16, 157. [CrossRef]

21. Asano, S. Granulomatous Lymphadenitis. J. Clin. Exp. Hematop. 2012, 52, 1-16. [CrossRef]

22. Kocabaş, E.; Özgür Gündeşlioğlu, Ö.; Kılıç Çil, M.; Çay, Ü.; Doran, F.; Soyupak, S. A Rare Cause of Granulomatous Hepatitis: Tularemia. J. Infect. Public Health 2020, 13, 1003-1005. [CrossRef] [PubMed]

23. Marth, T.; Moos, V.; Müller, C.; Biagi, F.; Schneider, T. Tropheryma Whipplei Infection and Whipple's Disease. Lancet Infect. Dis. 2016, 16, e13-e22. [CrossRef]

24. Lins, K.d.A.; Drummond, M.R.; Velho, P.E.N.F. Cutaneous Manifestations of Bartonellosis. An. Bras. Derm. 2019, 94, 594-602. [CrossRef] [PubMed]

25. Mabra, D.; Yeh, S.; Shantha, J.G. Ocular Manifestations of Bartonellosis. Curr. Opin. Ophthalmol. 2018, 29, 582-587. [CrossRef]

26. Murano, I.; Yoshii, H.; Kurashige, H.; Sugio, Y.; Tsukahara, M. Giant Hepatic Granuloma Caused by Bartonella Henselae. Pediatr. Infect. Dis. J. 2001, 20, 319-320. [CrossRef]

27. Drummond, M.R.; de Almeida, A.R.; Valandro, L.; Pavan, M.H.P.; Stucchi, R.S.B.; Aoki, F.H.; Velho, P.E.N.F. Bartonella Henselae Endocarditis in an Elderly Patient. PLoS Negl. Trop Dis. 2020, 14, e0008376. [CrossRef]

28. Delaby, A.; Gorvel, L.; Espinosa, L.; Lépolard, C.; Raoult, D.; Ghigo, E.; Capo, C.; Mege, J.-L. Defective Monocyte Dynamics in Q Fever Granuloma Deficiency. J. Infect. Dis. 2012, 205, 1086-1094. [CrossRef]

29. Szablewski, V.; Costes, V.; Rousset, T.; Mania, E.; El Aoufi, N. [Q fever: Bone marrow characteristic granuloma]. Ann. Pathol. 2012, 32, 263-266. [CrossRef]

30. Little, J.W. Syphilis: An Update. Oral Surg. Oral Med. Oral Pathol. Oral Radiol. Endodontol. 2005, 100, 3-9. [CrossRef]

31. Boyanova, L.; Kolarov, R.; Mateva, L.; Markovska, R.; Mitov, I. Actinomycosis: A Frequently Forgotten Disease. Future Microbiol. 2015, 10, 613-628. [CrossRef]

32. Wong, K.T.; Puthucheary, S.D.; Vadivelu, J. The Histopathology of Human Melioidosis. Histopathology 1995, 26, 51-55. [CrossRef]

33. Lamps, L.W.; Madhusudhan, K.T.; Greenson, J.K.; Pierce, R.H.; Massoll, N.A.; Chiles, M.C.; Dean, P.J.; Scott, M.A. The Role of Yersinia Enterocolitica and Yersinia Pseudotuberculosis in Granulomatous Appendicitis: A Histologic and Molecular Study. Am. J. Surg. Pathol. 2001, 25, 508-515. [CrossRef]

34. Belda Junior, W. Donovanosis. An. Bras. Derm. 2020, 95, 675-683. [CrossRef] [PubMed]

35. Mabey, D.; Peeling, R.W. Lymphogranuloma Venereum. Sex. Transm Infect. 2002, 78, 90-92. [CrossRef]

36. Bentata-Pessayre, M.; Beaugrand, M.; Callard, P.; Brun-Vesinet, F.; Krivitsky, A.; Mornet, P.; Delzant, G. [Granulomatous hepatitis in cytomegalovirus infection in healthy adults]. Ann. Med. Interne 1987, 138, 353-357.

37. Zhang, D.; Glover, S.C.; Liu, W.; Liu, X.; Lai, J. Small Bowel Pyogenic Granuloma With Cytomegalovirus Infection in a Patient With Crohn's Disease (Report of a Case and Review of the Literature). In Vivo 2019, 33, 251-254. [CrossRef] 
38. Alexandra, G.; Claudia, G. Lymphomatoid Granulomatosis Mimicking Cancer and Sarcoidosis. Ann. Hematol. 2019, 98, $1309-1311$. [CrossRef]

39. Martinez-Mera, C.; Hospital, M.; López-Negrete, E.; Suarez Massa, D. Atypical Herpes Simplex Presenting Necrotizing Granulomas in an Immunocompromised Patient. Am. J. Derm. 2020, 42, 305-306. [CrossRef] [PubMed]

40. McCoy, W.H.; Otchere, E.; Musiek, A.C.; Anadkat, M.J. Granulomatous Dermatitis as a Postherpetic Isotopic Response in Immunocompromised Patients: A Report of 5 Cases. JAAD Case Rep. 2018, 4, 752-760. [CrossRef]

41. Prieto Herman Reinehr, C.; Corrêa Martins, C.; Trein Cunha, V.; Elen Lira, F.; Sprinz, E.; Cartell, A.; Bakos, R.M. Cutaneous Human Immunodeficiency Virus (HIV)-Associated Lymphomatoid Granulomatosis: Complete Regression Following Antiretroviral Therapy. Int. J. Derm. 2017, 56, e100-e102. [CrossRef]

42. Costiniuk, C.T.; Karamchandani, J.; Bessissow, A.; Routy, J.-P.; Szabo, J.; Frenette, C. Angiocentric Lymph Proliferative Disorder (Lymphomatoid Granulomatosis) in a Person with Newly-Diagnosed HIV Infection: A Case Report. BMC Infect. Dis. 2018, 18, 210. [CrossRef]

43. Domínguez-Durán, E.; Luque-Márquez, R.; Fontillón-Alberdi, M.; Abrante-Jiménez, A. Laryngeal Lymphomatoid Granulomatosis in a HIV Patient. Enferm. Infecc. Microbiol. Clin. 2011, 29, 552-553. [CrossRef]

44. Tahan, V.; Ozaras, R.; Lacevic, N.; Ozden, E.; Yemisen, M.; Ozdogan, O.; Mert, A.; Tabak, F.; Avsar, E.; Celikel, C.A.; et al. Prevalence of Hepatic Granulomas in Chronic Hepatitis B. Dig. Dis. Sci. 2004, 49, 1575-1577. [CrossRef] [PubMed]

45. Ma, H.J.; Zhu, W.Y.; Yue, X.Z. Generalized Granuloma Annulare Associated with Chronic Hepatitis B Virus Infection. J. Eur. Acad. Derm. Venereol. 2006, 20, 186-189. [CrossRef]

46. Snyder, N.; Martinez, J.G.; Xiao, S.-Y. Chronic Hepatitis C Is a Common Associated with Hepatic Granulomas. World J. Gastroenterol. 2008, 14, 6366-6369. [CrossRef] [PubMed]

47. Vakiani, E.; Hunt, K.K.; Mazziotta, R.M.; Emond, J.C.; Brown, R.S.; Lefkowitch, J.H.; Bhagat, G. Hepatitis C-Associated Granulomas after Liver Transplantation: Morphologic Spectrum and Clinical Implications. Am. J. Clin. Pathol. 2007, 127, 128-134. [CrossRef] [PubMed]

48. García-Gil, M.F.; Monte Serrano, J.; García García, M.; Matovelle Ochoa, C.; Ara-Martín, M. Granuloma Annulare Triggered by SARS-CoV-2 Infection. The First Reported Case. J. Derm. 2021, 48, e1-e2. [CrossRef]

49. Monte-Serrano, J.; García-Gil, M.F.; García-García, M.; Casas-Flecha, I.; Matovelle-Ochoa, C.; Ara-Martín, M. Granuloma Annulare Triggered by SARS-CoV-2 Infection: Immunohistochemical Staining. Dermatol. Ther. 2021, e14897. [CrossRef]

50. Szajek, K.; Kajdi, M.-E.; Luyckx, V.A.; Fehr, T.H.; Gaspert, A.; Cusini, A.; Hohloch, K.; Grosse, P. Granulomatous Interstitial Nephritis in a Patient with SARS-CoV-2 Infection. BMC Nephrol. 2021, 22, 19. [CrossRef]

51. Schwartz, C.; Fallon, P.G. Schistosoma "Eggs-Iting" the Host: Granuloma Formation and Egg Excretion. Front. Immunol. 2018, 9, 2492. [CrossRef]

52. López Aventín, D.; Martín-Ezquerra, G.; Villar García, J.; Pujol, R.M. Immune Reconstitution-Associated Cutaneous Sarcoidlike Eruption in a Patient with Previous Disseminated Cutaneous Leishmaniasis: A Diagnostic Challenge. J. Dermatol. 2014, 41, 648-649. [CrossRef]

53. Giorgio, S.; Gallo-Francisco, P.H.; Roque, G.A.S.; Flóro e Silva, M. Granulomas in Parasitic Diseases: The Good and the Bad. Parasitol. Res. 2020, 119, 3165-3180. [CrossRef] [PubMed]

54. Bernard, C.; Maucort-Boulch, D.; Varron, L.; Charlier, C.; Sitbon, K.; Freymond, N.; Bouhour, D.; Hot, A.; Masquelet, A.C.; Valeyre, D.; et al. Cryptococcosis in Sarcoidosis: CryptOsarc, a Comparative Study of 18 Cases. QJM 2013, 106, 523-539. [CrossRef]

55. Sicherman, H.J.; Andersen, H.A.; DeRemee, R.A. Sarcoidosis or Fungal Disease? Chest 1973, 64, 36-38. [CrossRef] [PubMed]

56. Sundaram, C.; Murthy, J.M.K. Intracranial Aspergillus Granuloma. Pathol. Res. Int. 2011, 2011, e157320. [CrossRef]

57. Hartel, P.H.; Shilo, K.; Klassen-Fischer, M.; Neafie, R.C.; Franks, T.J. Granulomatous Reaction to Pneumocystis Jirovecii. Am. J. Surg. Pathol. 2010, 34, 5. [CrossRef] [PubMed]

58. Jeny, F.; Bernaudin, J.-F.; Cohen Aubart, F.; Brillet, P.-Y.; Bouvry, D.; Nunes, H.; Valeyre, D. Diagnosis Issues in Sarcoidosis. Respir. Med. Res. 2020, 77, 37-45. [CrossRef]

59. Agrawal, R.; Kee, A.R.; Ang, L.; Hang, Y.T.; Gupta, V.; Kon, O.M.; Mitchell, D.; Zierhutf, M.; Pavesio, C. Tuberculosis or Sarcoidosis: Opposite Ends of the Same Disease Spectrum? Tuberculosis 2016, 98. [CrossRef]

60. Piotrowski, W.J.; Białas, A.J.; Gwadera, Ł.; Kumor-Kisielewska, A.; Fijałkowski, M.; Kurmanowska, Z.; Marczak, J.; Gwadera, Ł.; Angowski, W.; Górski, P.; et al. QuantiFERON-TB-GOLD In-Tube in Patients with Sarcoidosis. Adv. Respir. Med. 2018, 86, 234-239. [CrossRef] [PubMed]

61. Walzl, G.; McNerney, R.; du Plessis, N.; Bates, M.; McHugh, T.D.; Chegou, N.N.; Zumla, A. Tuberculosis: Advances and Challenges in Development of New Diagnostics and Biomarkers. Lancet Infect. Dis. 2018, 18, e199-e210. [CrossRef]

62. Boehme, C.C.; Nabeta, P.; Hillemann, D.; Nicol, M.P.; Shenai, S.; Krapp, F.; Allen, J.; Tahirli, R.; Blakemore, R.; Rustomjee, R.; et al. Rapid Molecular Detection of Tuberculosis and Rifampin Resistance. N. Engl. J. Med. 2010, 363, 1005-1015. [CrossRef]

63. Li, S.; Liu, B.; Peng, M.; Chen, M.; Yin, W.; Tang, H.; Luo, Y.; Hu, P.; Ren, H. Diagnostic Accuracy of Xpert MTB/RIF for Tuberculosis Detection in Different Regions with Different Endemic Burden: A Systematic Review and Meta-Analysis. PLoS ONE 2017, 12. [CrossRef] [PubMed]

64. Mortaz, E.; Adcock, I.M.; Barnes, P.J. Sarcoidosis: Role of Non-Tuberculosis Mycobacteria and Mycobacterium Tuberculosis. Int. J. Mycobacteriol. 2014, 3, 225-229. [CrossRef] 
65. Lee, H.; Eom, M.; Kim, S.; Wang, H.; Lee, H.; Choi, E.H. Identification of Mycobacterium Tuberculosis and Non-tuberculous Mycobacteria from Cutaneous Sarcoidosis Lesions by Reverse Blot Hybridization Assay. J. Derm. 2019, 46, 917-921. [CrossRef] [PubMed]

66. Lisby, G.; Milman, N.; Jacobsen, G.K. Search for Mycobacterium Paratuberculosis DNA in Tissue from Patients with Sarcoidosis by Enzymatic Gene Amplification. APMIS 1993, 101, 876-878. [CrossRef] [PubMed]

67. Jeny, F.; Grutters, J.C. Experimental Models of Sarcoidosis: Where Are We Now? Curr. Opin. Pulm. Med. 2020, 26, 554-561. [CrossRef] [PubMed]

68. Tjwa, M.; De Hertogh, G.; Neuville, B.; Roskams, T.; Nevens, F.; Van Steenbergen, W. Hepatic Fibrin-Ring Granulomas in Granulomatous Hepatitis: Report of Four Cases and Review of the Literature. Acta Clin. Belg. 2001, 56, 341-348. [CrossRef]

69. Wheat, L.J.; Azar, M.M.; Bahr, N.C.; Spec, A.; Relich, R.F.; Hage, C. Histoplasmosis. Infect. Dis. Clin. North. Am. 2016, 30, 207-227. [CrossRef]

70. Shah, K.K.; Pritt, B.S.; Alexander, M.P. Histopathologic Review of Granulomatous Inflammation. J. Clin. Tuberc. Other Mycobact. Dis. 2017, 7, 1-12. [CrossRef] [PubMed]

71. Adigun, R.; Basit, H.; Murray, J. Cell Liquefactive Necrosis. In StatPearls; StatPearls Publishing: Treasure Island, FL, USA, 2021.

72. Brincker, H. Sarcoid Reactions and Sarcoidosis in Hodgkin's Disease and Other Malignant Lymphomata. Br. J. Cancer 1972, 26, 120-128. [CrossRef]

73. O'Connell, M.J. Epithelioid Granulomas in Hodgkin Disease. A Favorable Prognostic Sign? JAMA J. Am. Med. Assoc. 1975, 233, 886-889. [CrossRef]

74. Sacks, E.L.; Donaldson, S.S.; Gordon, J.; Dorfman, R.F. Epithelioid Granulomas Associated with Hodgkin's Disease. Clinical Correlations in 55 Previously Untreated Patients. Cancer 1978, 41, 562-567. [CrossRef]

75. Takeuchi, H.; Suchi, T.; Suzuki, R.; Sato, T. Histological Study of Immune Parameters of Regional Lymph Nodes of Gastric Cancer Patients. Gan 1982, 73, 420-428.

76. Steinfort, D.P.; Irving, L.B. Sarcoidal Reactions in Regional Lymph Nodes of Patients with Non-Small Cell Lung Cancer: Incidence and Implications for Minimally Invasive Staging with Endobronchial Ultrasound. Lung Cancer 2009, 66, 305-308. [CrossRef] [PubMed]

77. Arish, N.; Kuint, R.; Sapir, E.; Levy, L.; Abutbul, A.; Fridlender, Z.; Laxer, U.; Berkman, N. Characteristics of Sarcoidosis in Patients with Previous Malignancy: Causality or Coincidence? Respiration 2017, 93, 247-252. [CrossRef]

78. Hou, W.; Wei, P.; Xie, J.; Zheng, Y.; Zhou, X. Classical Hodgkin Lymphoma with Necrotic Granuloma-like Morphological Features. Int. J. Clin. Exp. Med. 2018, 11, 9593-9602.

79. Brincker, H.; Wilbek, E. The Incidence of Malignant Tumours in Patients with Respiratory Sarcoidosis. Br. J. Cancer 1974, 29, 247-251. [CrossRef]

80. Brincker, H. The Sarcoidosis-Lymphoma Syndrome. Br. J. Cancer 1986, 54, 467-473. [CrossRef]

81. Song, J.Y.; Pittaluga, S.; Dunleavy, K.; Grant, N.; White, T.; Jiang, L.; Davies-Hill, T.; Raffeld, M.; Wilson, W.H.; Jaffe, E.S. Lymphomatoid Granulomatosis-A Single Institute Experience: Pathologic Findings and Clinical Correlations. Am. J. Surg. Pathol. 2015, 39, 141-156. [CrossRef] [PubMed]

82. de Boysson, H.; Geffray, L. Granulomatose lymphomatoïde. Rev. Méd. Interne 2013, 34, 349-357. [CrossRef]

83. Padilla, M.L.; Schilero, G.J.; Teirstein, A.S. Donor-Acquired Sarcoidosis. Sarcoidosis Vasc Diffus. Lung Dis. 2002, $19,18-24$.

84. Morita, R.; Hashino, S.; Kubota, K.; Onozawa, M.; Kahata, K.; Kondo, T.; Suzuki, S.; Matsuno, Y.; Imamura, M.; Asaka, M. Donor Cell-Derived Sarcoidosis after Allogenic BMT. Bone Marrow Transplant. 2009, 43, 507-508. [CrossRef]

85. Schattenberg, A.V.M.B.; Baynes, C.; van Dijk, M.C.R.F.; Koster, A.; van Cleef, P.H.J.; Preijers, F.W.M.B.; Hermus, A.D.R.; Raemaekers, J.M.M. A Mediastinal Mass after Donor Lymphocyte Infusion for Relapse of Chronic Myeloid Leukemia after Allogeneic Stem Cell Transplantation. Leuk. Lymphoma 2006, 47, 1188-1190. [CrossRef] [PubMed]

86. Bhagat, R.; Rizzieri, D.A.; Vredenburgh, J.J.; Chao, N.J.; Folz, R.J. Pulmonary Sarcoidosis Following Stem Cell Transplantation. Chest 2004, 126, 642-644. [CrossRef] [PubMed]

87. Kushima, H.; Ishii, H.; Ikewaki, J.; Takano, K.; Ogata, M.; Kadota, J. Sarcoidosis in Donor-Derived Tissues after Haematopoietic Stem Cell Transplantation: Table 1. Eur. Respir. J. 2013, 41, 1452-1453. [CrossRef]

88. Marchal, A.; Charlotte, F.; Maksud, P.; Haroche, J.; Lifferman, F.; Miyara, M.; Choquet, S.; Amoura, Z.; Cohen Aubart, F. Sarcoidosis flare after autologous stem cell transplantation: An immune paradox? Rev. Med. Interne 2017, 38, 619-622. [CrossRef]

89. Landi, C.; Bargagli, E.; Carleo, A.; Bianchi, L.; Gagliardi, A.; Cillis, G.; Perari, M.G.; Refini, R.M.; Prasse, A.; Bini, L.; et al. A Functional Proteomics Approach to the Comprehension of Sarcoidosis. J. Proteom. 2015, 128, 375-387. [CrossRef]

90. Bicart-Sée, L.; Roriz, M.; Chabriat, H.; Buffon-Porcher, F.; Cognat, E. Neurosarcoidosis: Leptomeninigeal, Cavernous Sinus and Pituitary Involvement. QJM An. Int. J. Med. 2017, 110, 397-398. [CrossRef]

91. Bateman, A.C.; Ashton-Key, M.R.; Jogai, S. Lymph Node Granulomas in Immunoglobulin G4-Related Disease. Histopathology 2015, 67, 557-561. [CrossRef]

92. Bruce-Brand, C.; Schneider, J.W.; Schubert, P. Rosai-Dorfman Disease: An Overview. J. Clin. Pathol. 2020, 73, 697-705. [CrossRef]

93. Gaviria, J.G.; Johnson, D.A.; Kinney, M.C.; Proffer, L.H.; Losi-Sasaki, J.M.; Kraus, E.W. Bilateral Anterior Granulomatous Uveitis Associated with Cutaneous Rosai-Dorfman Disease. Graefes Arch. Clin. Exp. Ophthalmol. 2005, 243, 281-284. [CrossRef]

94. Johnston, J.M.; Limbrick, D.D.; Ray, W.Z.; Brown, S.; Shimony, J.; Park, T.S. Isolated Cerebellar Rosai-Dorfman Granuloma Mimicking Lhermitte-Duclos Disease: Case Report. J. Neurosurg. Pediatrics 2009, 4, 118-120. [CrossRef] 
95. McCarthy, E. Erdheim-Chester Disease. In Tumors and Tumor-Like Lesions of Bone: For Surgical Pathologists, Orthopedic Surgeons and Radiologists; Santini-Araujo, E., Kalil, R.K., Bertoni, F., Park, Y.-K., Eds.; Springer: London, UK, 2015; pp. 951-955, ISBN 978-1-4471-6578-1.

96. Gutmann, E.J. Granulomatous Inflammation Related to Amyloid Deposition in a Focus of Multiple Myeloma. Report of a Case with Diagnosis by Fine Needle Aspiration Biopsy. Acta Cytol. 1995, 39, 793-797. [PubMed]

97. Hirano, T.; Numakura, T.; Moriyama, H.; Saito, R.; Shishikura, Y.; Shiihara, J.; Sugiura, H.; Ichinose, M. The First Case of Multiple Pulmonary Granulomas with Amyloid Deposition in a Dental Technician; a Rare Manifestation as an Occupational Lung Disease. BMC Pulm. Med. 2018, 18, 77. [CrossRef]

98. Rao, N.A. Pathology of Vogt-Koyanagi-Harada Disease. Int. Ophthalmol. 2007, 27, 81-85. [CrossRef] [PubMed]

99. Caso, F.; Galozzi, P.; Costa, L.; Sfriso, P.; Cantarini, L.; Punzi, L. Autoinflammatory Granulomatous Diseases: From Blau Syndrome and Early-Onset Sarcoidosis to NOD2-Mediated Disease and Crohn's Disease. RMD Open 2015, 1. [CrossRef] [PubMed]

100. Torisu, Y.; Horai, Y.; Michitsuji, T.; Kawahara, C.; Mori, T.; Iwanaga, N.; Izumi, Y.; Kawakami, A. Giant Cell Arteritis with Generalized Granuloma Annulare. Intern. Med. 2019, 58, 1173-1177. [CrossRef]

101. Gómez-Mariscal, M.; Oleñik, A.; Arriba-Palomero, P.; García-Cosio, M.; Muñoz-Negrete, F.J. Recurrent Bilateral Anterior Uveitis with Kikuchi-Fujimoto Disease. Ocul. Immunol. Inflamm. 2017, 25, 866-869. [CrossRef]

102. Schwerd, T.; Pandey, S.; Yang, H.-T.; Bagola, K.; Jameson, E.; Jung, J.; Lachmann, R.H.; Shah, N.; Patel, S.Y.; Booth, C.; et al. Impaired Antibacterial Autophagy Links Granulomatous Intestinal Inflammation in Niemann-Pick Disease Type C1 and XIAP Deficiency with NOD2 Variants in Crohn's Disease. Gut 2017, 66, 1060-1073. [CrossRef]

103. Ohshimo, S.; Guzman, J.; Costabel, U.; Bonella, F. Differential Diagnosis of Granulomatous Lung Disease: Clues and Pitfalls: Number 4 in the Series "Pathology for the Clinician" Edited by Peter Dorfmüller and Alberto Cavazza. Eur. Respir. Rev. 2017, 26, 170012. [CrossRef]

104. Finkielman, J.D.; Lee, A.S.; Hummel, A.M.; Viss, M.A.; Jacob, G.L.; Homburger, H.A.; Peikert, T.; Hoffman, G.S.; Merkel, P.A.; Spiera, R.; et al. ANCA Are Detectable in Nearly All Patients with Active Severe Wegener's Granulomatosis. Am. J. Med. 2007, 120, 643.e9-643.e14. [CrossRef]

105. Rosen, Y. Four Decades of Necrotizing Sarcoid Granulomatosis: What Do We Know Now? Arch. Pathol. Lab. Med. 2015, 139, 252-262. [CrossRef] [PubMed]

106. Kallel, L.; Fekih, M.; Ghorbel, I.B.; Chelly, I.; Houman, H.; Filali, A. Un cas exceptionnel de sarcoïdose systémique suivie par une maladie de Crohn: Une association fortuite ou lien étiopathogénique? Presse Méd. 2010, 39, 148-150. [CrossRef]

107. Rajoriya, N.; Wotton, C.J.; Yeates, D.G.R.; Travis, S.P.L.; Goldacre, M.J. Immune-Mediated and Chronic Inflammatory Disease in People with Sarcoidosis: Disease Associations in a Large UK Database. Postgrad. Med. J. 2009, 85, 233-237. [CrossRef] [PubMed]

108. Halling, M.L.; Kjeldsen, J.; Knudsen, T.; Nielsen, J.; Hansen, L.K. Patients with Inflammatory Bowel Disease Have Increased Risk of Autoimmune and Inflammatory Diseases. World J. Gastroenterol. 2017, 23, 6137-6146. [CrossRef] [PubMed]

109. Ghrenassia, E.; Mekinian, A.; Chapelon-Albric, C.; Levy, P.; Cosnes, J.; Sève, P.; Lefèvre, G.; Dhôte, R.; Launay, D.; Prendki, V.; et al. Digestive-Tract Sarcoidosis: French Nationwide Case-Control Study of 25 Cases. Medicine 2016, 95, e4279. [CrossRef] [PubMed]

110. Brown, I.; Kumarasinghe, M.P. Granulomas in the Gastrointestinal Tract: Deciphering the Pandora's Box. Virchows Arch. 2018, 472, 3-14. [CrossRef] [PubMed]

111. Hugot, J.P.; Chamaillard, M.; Zouali, H.; Lesage, S.; Cézard, J.P.; Belaiche, J.; Almer, S.; Tysk, C.; O’Morain, C.A.; Gassull, M.; et al. Association of NOD2 Leucine-Rich Repeat Variants with Susceptibility to Crohn's Disease. Nature 2001, 411, 599-603. [CrossRef]

112. Martin, J.; Kodjikian, L.; Duquesne, A.; Le Scanff, J.; Sève, P. Blau Syndrome. QJM An. Int. J. Med. 2011, 104, 997-998. [CrossRef]

113. Aróstegui, J.I.; Arnal, C.; Merino, R.; Modesto, C.; Antonia Carballo, M.; Moreno, P.; García-Consuegra, J.; Naranjo, A.; Ramos, E.; de Paz, P.; et al. NOD2 Gene-Associated Pediatric Granulomatous Arthritis: Clinical Diversity, Novel and Recurrent Mutations, and Evidence of Clinical Improvement with Interleukin-1 Blockade in a Spanish Cohort. Arthritis Rheum 2007, 56, 3805-3813. [CrossRef]

114. Poline, J.; Fogel, O.; Pajot, C.; Miceli-Richard, C.; Rybojad, M.; Galeotti, C.; Grouteau, E.; Hachulla, E.; Brissaud, P.; Cantagrel, A.; et al. Early-Onset Granulomatous Arthritis, Uveitis and Skin Rash: Characterization of Skin Involvement in Blau Syndrome. J. Eur. Acad. Dermatol. Venereol. 2020, 34, 340-348. [CrossRef] [PubMed]

115. Caso, F.; Costa, L.; Rigante, D.; Vitale, A.; Cimaz, R.; Lucherini, O.M.; Sfriso, P.; Verrecchia, E.; Tognon, S.; Bascherini, V.; et al. Caveats and Truths in Genetic, Clinical, Autoimmune and Autoinflammatory Issues in Blau Syndrome and Early Onset Sarcoidosis. Autoimmun. Rev. 2014, 13, 1220-1229. [CrossRef]

116. Rosé, C.D.; Pans, S.; Casteels, I.; Anton, J.; Bader-Meunier, B.; Brissaud, P.; Cimaz, R.; Espada, G.; Fernandez-Martin, J.; Hachulla, E.; et al. Blau Syndrome: Cross-Sectional Data from a Multicentre Study of Clinical, Radiological and Functional Outcomes. Rheumatology 2015, 54, 1008-1016. [CrossRef] [PubMed]

117. Stoevesandt, J.; Morbach, H.; Martin, T.M.; Zierhut, M.; Girschick, H.; Hamm, H. Sporadic Blau Syndrome with Onset of Widespread Granulomatous Dermatitis in the Newborn Period. Pediatr. Derm. 2010, 27, 69-73. [CrossRef]

118. Imayoshi, M.; Ogata, Y.; Yamamoto, S. A Case of Sporadic Blau Syndrome with an Uncommon Clinical Course. Case Rep. Rheumatol. 2018, 2018. [CrossRef]

119. Chopra, A.; Nautiyal, A.; Kalkanis, A.; Judson, M.A. Drug-Induced Sarcoidosis-Like Reactions. Chest 2018, $154,664-677$. [CrossRef] 
120. Ramos-Casals, M.; Mañá, J.; Nardi, N.; Brito-Zerón, P.; Xaubet, A.; Sánchez-Tapias, J.M.; Cervera, R.; Font, J. Sarcoidosis in Patients With Chronic Hepatitis C Virus Infection: Analysis of 68 Cases. Medicine 2005, 84, 69-80. [CrossRef] [PubMed]

121. Rodrigues-Fernandes, C.I.; Migliorati, C.A.; Gueiros, L.A.M.; de Lima Morais, T.M.; Vargas, P.A.; de Almeida, O.P.; Lopes, M.A.; Santos-Silva, A.R. Adalimumab-Induced Sarcoidosis-like Reaction Involving Oral Cavity in Rheumatoid Arthritis: A Case-Based Review. Clin. Rheumatol. 2021. [CrossRef] [PubMed]

122. Cohen Aubart, F.; Lhote, R.; Amoura, A.; Valeyre, D.; Haroche, J.; Amoura, Z.; Lebrun-Vignes, B. Drug-induced Sarcoidosis: An Overview of the WHO Pharmacovigilance Database. J. Intern. Med. 2019. [CrossRef]

123. Mayer, A.; Hamzeh, N.; Maier, L. Sarcoidosis and Chronic Beryllium Disease: Similarities and Differences. Semin. Respir. Crit. Care Med. 2014, 35, 316-329. [CrossRef]

124. Chong, H.; Brady, K.; Metze, D.; Calonje, E. Persistent Nodules at Injection Sites (Aluminium Granuloma) - Clinicopathological Study of 14 Cases with a Diverse Range of Histological Reaction Patterns. Histopathology 2006, 48, 182-188. [CrossRef]

125. Igbokwe, I.O.; Igwenagu, E.; Igbokwe, N.A. Aluminium Toxicosis: A Review of Toxic Actions and Effects. InterDis.cip Toxicol 2019, 12, 45-70. [CrossRef]

126. Hou, M.; Zhu, W.; Ye, Y. Cutaneous Silica Granuloma with Generalized Involvement of Lymph Nodes. J. Derm. 2011, 38, 697-701. [CrossRef]

127. Ligthelm, A.J.; Bütow, K.W.; Weber, A. Silica Granuloma of a Lymph Node. Int. J. Oral. Maxillofac. Surg. 1988, 17, $352-353$. [CrossRef]

128. Mowry, R.G.; Sams, W.M.; Caulfield, J.B. Cutaneous Silica Granuloma. A Rare Entity or Rarely Diagnosed? Report of Two Cases with Review of the Literature. Arch. Derm. 1991, 127, 692-694. [CrossRef]

129. Nakata, T.; Suzuki, M.; Maruo, M.; Yamasaki, Y.; Ishida, K.; Kudo, A.; Hashinaga, E.; Aoki, K.; Higashi, H.; Nawata, T.; et al. Granulomatous Interstitial Nephritis Associated with Silica. Nephrology 2018, 23, 190. [CrossRef]

130. Creery, R.D.; Mcclure, D.M.; Rutherford, R.J. Talc Granuloma of the Umbilicus. Lancet 1957, 272, 667-668. [CrossRef] [PubMed]

131. Jasuja, S.; Kuhn, B.T.; Schivo, M.; Adams, J.Y. Cosmetic Talc-Related Pulmonary Granulomatosis. J. Investig. Med. High Impact Case Rep. 2017, 5, 2324709617728527. [CrossRef]

132. Molos, M.A.; Litton, N.; Schubert, T.T. Talc Liver. J. Clin. Gastroenterol. 1987, 9, 198-203. [CrossRef] [PubMed]

133. Pelstring, R.J.; Kim, C.K.; Lower, E.E.; Swerdlow, S.H. Marrow Granulomas in Coal Workers' Pneumoconiosis. A Histologic Study with Elemental Analysis. Am. J. Clin. Pathol. 1988, 89, 553-556. [CrossRef]

134. Salvador, G.L. de O.; Barbieri, P.P.; Maschke, L.; Nunes, A.L.A.; Louveira, M.H.; Budel, V.M. Charcoal Granuloma Mimicking Breast Cancer: An Emerging Diagnosis. Acta Radiol. Open 2018, 7. [CrossRef]

135. Gavoille, A.; Vincent, M.; Kiakouama, L.; Catinon, M.; Lamkhioued, M.; Devouassoux, M.; Grumet, P.; Jamilloux, Y.; Sève, P. Sarcoidosis after Breast Implant Rupture: Looking beyond Granulomas. Autoimmun. Rev. 2020, 19, 102673. [CrossRef] [PubMed]

136. Yoshida, T.; Tanaka, M.; Okamoto, K.; Hirai, S. Neurosarcoidosis Following Augmentation Mammoplasty with Silicone. Neurol. Res. 1996, 18, 319-320. [CrossRef]

137. Nutz, A.; Pernet, C.; Combe, B.; Cohen, J.-D. Sarcoidosis Induced by Tocilizumab: A Paradoxical Event? J. Rheumatol. 2013, 40, 1773-1774. [CrossRef] [PubMed]

138. Bustamente, L.; Buscot, M.; Marquette, C.H.; Roux, C. Sarcoidosis and Tocilizumab: Is There a Link? Clin. Exp. Rheumatol. 2017, 35,716 .

139. Del Giorno, R.; Iodice, A.; Mangas, C.; Gabutti, L. New-Onset Cutaneous Sarcoidosis under Tocilizumab Treatment for Giant Cell Arteritis: A Quasi-Paradoxical Adverse Drug Reaction. Case Report and Literature Review. Ther. Adv. Musculoskelet. Dis. 2019, 11, 1759720X1984179. [CrossRef]

140. Shono, Y.; Kamata, M.; Takeoka, S.; Ikawa, T.; Tateishi, M.; Fukaya, S.; Hayashi, K.; Fukuyasu, A.; Tanaka, T.; Ishikawa, T.; et al. Cutaneous Sarcoidosis in a Patient with Rheumatoid Arthritis Receiving Tocilizumab. J. Derm. 2018, 45, e217-e218. [CrossRef]

141. Theodosiou, G.; Luu, H.; Svensson, Å. Tocilizumab-Induced Sarcoidosis-like Reaction in a Patient with Giant Cell Arteritis. Clinical Implications of a Paradoxical Phenomenon. Int. J. Derm. 2020, 59, 888-889. [CrossRef]

142. Le Burel, S.; Champiat, S.; Mateus, C.; Marabelle, A.; Michot, J.-M.; Robert, C.; Belkhir, R.; Soria, J.-C.; Laghouati, S.; Voisin, A.-L.; et al. Prevalence of Immune-Related Systemic Adverse Events in Patients Treated with Anti-Programmed Cell Death 1/Anti-Programmed Cell Death-Ligand 1 Agents: A Single-Centre Pharmacovigilance Database Analysis. Eur. J. Cancer 2017, 82, 34-44. [CrossRef]

143. Jespersen, H.; Bjursten, S.; Ny, L.; Levin, M. Checkpoint Inhibitor-Induced Sarcoid Reaction Mimicking Bone Metastases. Lancet Oncol. 2018, 19, e327. [CrossRef]

144. Kim, S.T.; Pundole, X.; Dadu, R.; Lambotte, O.; Ramos-Casals, M.; Suarez-Almazor, M.E. Use of Immune Checkpoint Inhibitors in Cancer Patients with Pre-Existing Sarcoidosis. Immunotherapy 2021, 13, 465-475. [CrossRef]

145. Balbouzis, T.; Georgiadis, T.; Grigoris, P. Granulomatous Lung Disease: A Novel Complication Following Metallosis from Hip Arthroplasty. Hip Pelvis 2016, 28, 249-253. [CrossRef] [PubMed]

146. Shoenfeld, Y.; Agmon-Levin, N. "ASIA"-Autoimmune/Inflammatory Syndrome Induced by Adjuvants. J. Autoimmun. 2011, 36, 4-8. [CrossRef] [PubMed]

147. Cohen Tervaert, J.W. Autoinflammatory/Autoimmunity Syndrome Induced by Adjuvants (ASIA.; Shoenfeld's Syndrome): A New Flame. Autoimmun. Rev. 2018, 17, 1259-1264. [CrossRef] 
148. Tangye, S.G.; Al-Herz, W.; Bousfiha, A.; Cunningham-Rundles, C.; Franco, J.L.; Holland, S.M.; Klein, C.; Morio, T.; Oksenhendler, E.; Picard, C.; et al. The Ever-Increasing Array of Novel Inborn Errors of Immunity: An Interim Update by the IUIS Committee. J. Clin. Immunol. 2021, 41, 666-679. [CrossRef] [PubMed]

149. Tangye, S.G.; Al-Herz, W.; Bousfiha, A.; Chatila, T.; Cunningham-Rundles, C.; Etzioni, A.; Franco, J.L.; Holland, S.M.; Klein, C.; Morio, T.; et al. Human Inborn Errors of Immunity: 2019 Update on the Classification from the International Union of Immunological Societies Expert Committee. J. Clin. Immunol. 2020, 40, 24-64. [CrossRef] [PubMed]

150. Chapel, H.; Cunningham-Rundles, C. Update in Understanding Common Variable Immunodeficiency Disorders (CVIDs) and the Management of Patients with These Conditions. Br. J. Haematol. 2009, 145, 709-727. [CrossRef]

151. Bonilla, F.A.; Barlan, I.; Chapel, H.; Costa-Carvalho, B.T.; Cunningham-Rundles, C.; de la Morena, M.T.; Espinosa-Rosales, F.J.; Hammarström, L.; Nonoyama, S.; Quinti, I.; et al. International Consensus Document (ICON): Common Variable Immunodeficiency Disorders. J. Allergy Clin. Immunol. Pract. 2016, 4, 38-59. [CrossRef] [PubMed]

152. Bertinchamp, R.; Gérard, L.; Boutboul, D.; Malphettes, M.; Fieschi, C.; Oksenhendler, E.; DEFI study Group. Exclusion of Patients with a Severe T-Cell Defect Improves the Definition of Common Variable Immunodeficiency. J. Allergy Clin. Immunol. Pract. 2016, 4, 1147-1157. [CrossRef]

153. Prasad, R. Pulmonary Sarcoidosis and Chronic Cutaneous Atypical Mycobacter Ulcer. Aust. Fam. Physician 1993, $22,755-758$. [PubMed]

154. Fasano, M.B.; Sullivan, K.E.; Sarpong, S.B.; Wood, R.A.; Jones, S.M.; Johns, C.J.; Lederman, H.M.; Bykowsky, M.J.; Greene, J.M.; Winkelstein, J.A. Sarcoidosis and Common Variable Immunodeficiency. Report of 8 Cases and Review of the Literature. Medicine 1996, 75, 251-261. [CrossRef]

155. Nunes, H.; Bouvry, D.; Soler, P.; Valeyre, D. Sarcoidosis. Orphanet J. Rare Dis. 2007, 2, 46. [CrossRef]

156. Hunninghake, G.W.; Crystal, R.G. Mechanisms of Hypergammaglobulinemia in Pulmonary Sarcoidosis. J. Clin. Invest. 1981, 67, 86-92. [CrossRef]

157. Bouvry, D.; Mouthon, L.; Brillet, P.-Y.; Kambouchner, M.; Ducroix, J.-P.; Cottin, V.; Haroche, J.; Viallard, J.-F.; Lazor, R.; Lebargy, F.; et al. Granulomatosis-Associated Common Variable Immunodeficiency Disorder: A Case-Control Study versus Sarcoidosis. Eur. Respir. J. 2013, 41, 115-122. [CrossRef]

158. Jamee, M.; Hosseinzadeh, S.; Sharifinejad, N.; Zaki-Dizaji, M.; Matloubi, M.; Hasani, M.; Baris, S.; Alsabbagh, M.; Lo, B.; Azizi, G. Comprehensive Comparison between 222 CTLA-4 Haploinsufficiency and 212 LRBA Deficiency Patients: A Systematic Review. Clin. Exp. Immunol. 2021. [CrossRef]

159. Schwab, C.; Gabrysch, A.; Olbrich, P.; Patiño, V.; Warnatz, K.; Wolff, D.; Hoshino, A.; Kobayashi, M.; Imai, K.; Takagi, M.; et al. Phenotype, Penetrance, and Treatment of 133 CTLA-4-Insufficient Subjects. J. Allergy Clin. Immunol. 2018, 142, $1932-1946$. [CrossRef] [PubMed]

160. Schindler, M.K.; Pittaluga, S.; Enose-Akahata, Y.; Su, H.C.; Rao, V.K.; Rump, A.; Jacobson, S.; Cortese, I.; Reich, D.S.; Uzel, G. Haploinsufficiency of Immune Checkpoint Receptor CTLA4 Induces a Distinct Neuroinflammatory Disorder. J. Clin. Invest. 2020, 130, 5551-5561. [CrossRef] [PubMed]

161. Roos, D. Chronic Granulomatous Disease. Br. Med. Bull. 2016, 118, 50-63. [CrossRef] [PubMed]

162. Salvator, H.; Mahlaoui, N.; Catherinot, E.; Rivaud, E.; Pilmis, B.; Borie, R.; Crestani, B.; Tcherakian, C.; Suarez, F.; Dunogue, B.; et al. Pulmonary Manifestations in Adult Patients with Chronic Granulomatous Disease. Eur. Respir. J. 2015, 45, 1613-1623. [CrossRef] [PubMed]

163. Mather, M.W.; Hayhurst, H.; Bacon, C.M.; Cole, T.S.; Pan-Hammarström, Q.; Misbah, S.; Gennery, A.R. Mutation of TNFRSF13B in a Child with 22q11 Deletion Syndrome Associated with Granulomatous Lymphoproliferation. J. Allergy Clin. Immunol. 2015, 135, 559-561. [CrossRef] [PubMed]

164. Germinaro, M.; Reynolds, P.; Knight, V.; Alam, R. Association of B-Cell Activating Factor Receptor Deficiency with the P21R Polymorphism and Common Variable Immunodeficiency. Ann. Allergy Asthma Immunol. 2015, 115, 82-83. [CrossRef] [PubMed]

165. Yu, H.-H.; Yang, Y.-H.; Chiang, B.-L. Chronic Granulomatous Disease: A Comprehensive Review. Clin. Rev. Allerg. Immunol. 2020. [CrossRef] [PubMed]

166. De Ravin, S.S.; Cowen, E.W.; Zarember, K.A.; Whiting-Theobald, N.L.; Kuhns, D.B.; Sandler, N.G.; Douek, D.C.; Pittaluga, S.; Poliani, P.L.; Lee, Y.N.; et al. Hypomorphic Rag Mutations Can Cause Destructive Midline Granulomatous Disease. Blood 2010, 116, 1263-1271. [CrossRef] [PubMed]

167. Law-Ping-Man, S.; Toutain, F.; Rieux-Laucat, F.; Picard, C.; Kammerer-Jacquet, S.; Magérus-Chatinet, A.; Dupuy, A.; Adamski, H. Chronic Granulomatous Skin Lesions Leading to a Diagnosis of TAP1 Deficiency Syndrome. Pediatr. Derm. 2018, 35, e375-e377. [CrossRef] [PubMed]

168. Aderibigbe, O.M.; Priel, D.L.; Lee, C.-C.R.; Ombrello, M.J.; Prajapati, V.H.; Liang, M.G.; Lyons, J.J.; Kuhns, D.B.; Cowen, E.W.; Milner, J.D. Distinct Cutaneous Manifestations and Cold-Induced Leukocyte Activation Associated With PLCG2 Mutations. Jama Derm. 2015, 151, 627-634. [CrossRef]

169. Woelke, S.; Valesky, E.; Bakhtiar, S.; Pommerening, H.; Pfeffermann, L.M.; Schubert, R.; Zielen, S. Treatment of Granulomas in Patients With Ataxia Telangiectasia. Front. Immunol. 2018, 9. [CrossRef]

170. Jiang, Y.; Firan, M.; Nandiwada, S.L.; Reyes, A.; Marsh, R.A.; Vogel, T.P.; Hajjar, J. The Natural History of X-Linked Lymphoproliferative Disease (XLP1): Lessons from a Long-Term Survivor. Case Rep. Immunol. 2020, 2020. [CrossRef] 
171. Salvaggio, H.L.; Graeber, K.E.; Clarke, L.E.; Schlosser, B.J.; Orlow, S.J.; Clarke, J.T. Mucocutaneous Granulomatous Disease in a Patient With Hermansky-Pudlak Syndrome. JAMA Derm. 2014, 150, 1083. [CrossRef]

172. Schinella, R.A.; Greco, M.A.; Cobert, B.L.; Denmark, L.W.; Cox, R.P. Hermansky-Pudlak Syndrome with Granulomatous Colitis. Ann. Intern. Med. 1980, 92, 20-23. [CrossRef]

173. Corvilain, E.; Casanova, J.-L.; Puel, A. Inherited CARD9 Deficiency: Invasive Disease Caused by Ascomycete Fungi in Previously Healthy Children and Adults. J. Clin. Immunol. 2018, 38, 656-693. [CrossRef]

174. Pacheco, Y.; Lim, C.X.; Weichhart, T.; Valeyre, D.; Bentaher, A.; Calender, A. Sarcoidosis and the MTOR, Rac1, and Autophagy Triad. Trends Immunol. 2020, 41, 286-299. [CrossRef] [PubMed]

175. Jamilloux, Y.; Néel, A.; Lecouffe-Desprets, M.; Fèvre, A.; Kerever, S.; Guillon, B.; Bouvry, D.; Varron, L.; Redares, C.; Dominique, S. Progressive Multifocal Leukoencephalopathy in Patients with Sarcoidosis. Neurology 2014, 82, 1307-1313. [CrossRef] [PubMed]

176. Latgé, J.-P.; Chamilos, G. Aspergillus Fumigatus and Aspergillosis in 2019. Clin. Microbiol. Rev. 2019, 33. [CrossRef] [PubMed]

177. Uzunhan, Y.; Nunes, H.; Jeny, F.; Lacroix, M.; Brun, S.; Brillet, P.-Y.; Martinod, E.; Carette, M.-F.; Bouvry, D.; Charlier, C.; et al. Chronic Pulmonary Aspergillosis Complicating Sarcoidosis. Eur. Respir. J. 2017, 49. [CrossRef]

178. Miyara, M.; Amoura, Z.; Parizot, C.; Badoual, C.; Dorgham, K.; Trad, S.; Kambouchner, M.; Valeyre, D.; Chapelon-Abric, C.; Debré, P.; et al. The Immune Paradox of Sarcoidosis and Regulatory T Cells. J. Exp. Med. 2006, 203, 359-370. [CrossRef]

179. Espert, L.; Beaumelle, B.; Vergne, I. Autophagy in Mycobacterium Tuberculosis and HIV Infections. Front. Cell Infect. Microbiol. 2015, 5. [CrossRef]

180. Kim, Y.S.; Silwal, P.; Kim, S.Y.; Yoshimori, T.; Jo, E.-K. Autophagy-Activating Strategies to Promote Innate Defense against Mycobacteria. Exp. Mol. Med. 2019, 51,1-10. [CrossRef] [PubMed]

181. Nicola, A.M.; Albuquerque, P.; Martinez, L.R.; Dal-Rosso, R.A.; Saylor, C.; De Jesus, M.; Nosanchuk, J.D.; Casadevall, A. Macrophage Autophagy in Immunity to Cryptococcus Neoformans and Candida Albicans. Infect. Immun. 2012, 80, 3065-3076. [CrossRef] [PubMed]

182. Jamilloux, Y.; Cohen-Aubart, F.; Chapelon-Abric, C.; Maucort-Boulch, D.; Marquet, A.; Pérard, L.; Bouillet, L.; Deroux, A.; Abad, S.; Bielefeld, P.; et al. Efficacy and Safety of Tumor Necrosis Factor Antagonists in Refractory Sarcoidosis: A Multicenter Study of 132 Patients. Semin. Arthritis Rheum. 2017, 47, 288-294. [CrossRef] [PubMed]

183. Sweiss, N.J.; Salloum, R.; Ghandi, S.; Alegre, M.-L.; Sawaqed, R.; Badaracco, M.; Pursell, K.; Pitrak, D.; Baughman, R.P.; Moller, D.R.; et al. Significant CD4, CD8, and CD19 Lymphopenia in Peripheral Blood of Sarcoidosis Patients Correlates with Severe Disease Manifestations. PLoS ONE 2010, 5, e9088. [CrossRef]

184. Guffroy, A.; Solis, M.; Gies, V.; Dieudonne, Y.; Kuhnert, C.; Lenormand, C.; Kremer, L.; Molitor, A.; Carapito, R.; Hansmann, Y.; et al. Progressive Multifocal Leukoencephalopathy and Sarcoidosis under Interleukin 7: The Price of Healing. Neurol. Neuroimmunol. Neuroinflamm. 2020, 7. [CrossRef] [PubMed]

185. Jarius, S.; Ruprecht, K.; Kleiter, I.; Borisow, N.; Asgari, N.; Pitarokoili, K.; Pache, F.; Stich, O.; Beume, L.-A.; Hümmert, M.W.; et al. MOG-IgG in NMO and Related Disorders: A Multicenter Study of 50 Patients. Part 1: Frequency, Syndrome Specificity, Influence of Disease Activity, Long-Term Course, Association with AQP4-IgG, and Origin. J. Neuroinflamm. 2016, 13, 279. [CrossRef] [PubMed]

186. Ramanathan, S.; Fraser, C.; Curnow, S.R.; Ghaly, M.; Leventer, R.J.; Lechner-Scott, J.; Henderson, A.; Reddel, S.; Dale, R.C.; Brilot, F. Uveitis and Optic Perineuritis in the Context of Myelin Oligodendrocyte Glycoprotein Antibody Seropositivity. Eur. J. Neurol. 2019, 26, 1137-e75. [CrossRef]

187. Stern, B.J.; Royal, W.; Gelfand, J.M.; Clifford, D.B.; Tavee, J.; Pawate, S.; Berger, J.R.; Aksamit, A.J.; Krumholz, A.; Pardo, C.A.; et al. Definition and Consensus Diagnostic Criteria for Neurosarcoidosis: From the Neurosarcoidosis Consortium Consensus Group. JAMA Neurol 2018, 75, 1546. [CrossRef]

188. Voortman, M.; Drent, M.; Baughman, R.P. Management of Neurosarcoidosis: A Clinical Challenge. Curr. Opin. Neurol. 2019, 32, 475-483. [CrossRef] [PubMed]

189. Hoitsma, E.; Faber, C.G.; Drent, M.; Sharma, O.P. Neurosarcoidosis: A Clinical Dilemma. Lancet Neurol. $2004,3,397-407$. [CrossRef]

190. Kidd, D.P. Neurosarcoidosis: Clinical Manifestations, Investigation and Treatment. Pract. Neurol. 2020, 20, 199-212. [CrossRef]

191. Fritz, D.; van de Beek, D.; Brouwer, M.C. Clinical Features, Treatment and Outcome in Neurosarcoidosis: Systematic Review and Meta-Analysis. BMC Neurol. 2016, 16, 220. [CrossRef]

192. Chazal, T.; Costopoulos, M.; Maillart, E.; Fleury, C.; Psimaras, D.; Legendre, P.; Pineton de Chambrun, M.; Haroche, J.; Lubetzki, C.; Amoura, Z.; et al. The Cerebrospinal Fluid CD4/CD8 Ratio and Interleukin-6 and -10 Levels in Neurosarcoidosis: A Multicenter, Pragmatic, Comparative Study. Eur. J. Neurol. 2019, 26, 1274-1280. [CrossRef]

193. Thompson, A.J.; Banwell, B.L.; Barkhof, F.; Carroll, W.M.; Coetzee, T.; Comi, G.; Correale, J.; Fazekas, F.; Filippi, M.; Freedman, M.S.; et al. Diagnosis of Multiple Sclerosis: 2017 Revisions of the McDonald Criteria. Lancet Neurol. 2018, 17, 162-173. [CrossRef]

194. Maggi, P.; Absinta, M.; Sati, P.; Perrotta, G.; Massacesi, L.; Dachy, B.; Pot, C.; Meuli, R.; Reich, D.S.; Filippi, M.; et al. The “Central Vein Sign" in Patients with Diagnostic "Red Flags" for Multiple Sclerosis: A Prospective Multicenter 3T Study. Mult. Scler. J. 2020, 26, 421-432. [CrossRef]

195. Braithwaite, T.; Subramanian, A.; Petzold, A.; Galloway, J.; Adderley, N.J.; Mollan, S.P.; Plant, G.T.; Nirantharakumar, K.; Denniston, A.K. Trends in Optic Neuritis Incidence and Prevalence in the UK and Association With Systemic and Neurologic Disease. JAMA Neurol. 2020, 77, 1514-1523. [CrossRef] 
196. Flanagan, E.P.; Kaufmann, T.J.; Krecke, K.N.; Aksamit, A.J.; Pittock, S.J.; Keegan, B.M.; Giannini, C.; Weinshenker, B.G. Discriminating Long Myelitis of Neuromyelitis Optica from Sarcoidosis. Ann. Neurol. 2016, 79, 437-447. [CrossRef] [PubMed]

197. Cobo-Calvo, A.; Vukusic, S.; Marignier, R. Clinical Spectrum of Central Nervous System Myelin Oligodendrocyte Glycoprotein Autoimmunity in Adults. Curr Opin Neurol 2019, 32, 459-466. [CrossRef] [PubMed]

198. Saygin, D.; Jones, S.; Sundaram, P.; Calabrese, L.H.; Messner, W.; Tavee, J.O.; Hajj-Ali, R.A. Differentiation between Neurosarcoidosis and Primary Central Nervous System Vasculitis Based on Demographic, Cerebrospinal and Imaging Features. Clin. Exp. Rheumatol. 2020, 38 (Suppl 124), 135-138.

199. Taieb, G.; Mulero, P.; Psimaras, D.; van Oosten, B.W.; Seebach, J.D.; Marignier, R.; Pico, F.; Rigau, V.; Ueno, Y.; Duflos, C.; et al. CLIPPERS and Its Mimics: Evaluation of New Criteria for the Diagnosis of CLIPPERS. J. Neurol. Neurosurg. Psychiatry 2019, 90, 1027-1038. [CrossRef]

200. Kunchok, A.; Zekeridou, A.; McKeon, A. Autoimmune Glial Fibrillary Acidic Protein Astrocytopathy. Curr. Opin. Neurol. 2019, 32, 452-458. [CrossRef] [PubMed]

201. Schaller, M.A.; Wicke, F.; Foerch, C.; Weidauer, S. Central Nervous System Tuberculosis: Etiology, Clinical Manifestations and Neuroradiological Features. Clin. Neuroradiol. 2019, 29, 3-18. [CrossRef] [PubMed]

202. Leonhard, S.E.; Fritz, D.; van de Beek, D.; Brouwer, M.C. Cryptococcal Meningitis Complicating Sarcoidosis. Medicine 2016, 95, e4587. [CrossRef]

203. Meliou, M.; Mavridis, I.N.; Pyrgelis, E.-S.; Agapiou, E. Toxocariasis of the Nervous System. Acta Parasitol. 2020, 65, 291-299. [CrossRef]

204. Wartique, L.; Jamilloux, Y.; De Parisot De Bernecourt, A.; Kodjikian, L.; Ghesquieres, H.; Ide, C.; Sève, P. Development of Vitreoretinal Lymphoma in a Patient with Sarcoid Uveitis. Ocul. Immunol. Inflamm. 2020, 28, 647-650. [CrossRef] [PubMed]

205. He, C.; Wang, Y.; Zhang, L.; Lu, C.; Ge, W.; Zhang, Q.; Gui, Q.; Liu, R.; Yu, S. Isolated Lymphomatoid Granulomatosis of the Central Nervous System: A Case Report and Literature Review. Neuropathology 2019, 39, 479-488. [CrossRef] [PubMed]

206. Grois, N.; Fahrner, B.; Arceci, R.J.; Henter, J.-I.; McClain, K.; Lassmann, H.; Nanduri, V.; Prosch, H.; Prayer, D.; Histiocyte Society CNS LCH Study Group. Central Nervous System Disease in Langerhans Cell Histiocytosis. J. Pediatr. 2010, 156, 873-881. [CrossRef]

207. Pan, Z.; Kleinschmidt-DeMasters, B.K. CNS Erdheim-Chester Disease: A Challenge to Diagnose. J. Neuropathol. Exp. Neurol. 2017, 76, 986-996. [CrossRef]

208. Borhani-Haghighi, A.; Kardeh, B.; Banerjee, S.; Yadollahikhales, G.; Safari, A.; Sahraian, M.A.; Shapiro, L. Neuro-Behcet's Disease: An Update on Diagnosis, Differential Diagnoses, and Treatment. Mult. Scler. Relat. Disord. 2019, 39, 101906. [CrossRef]

209. Marques, C.; Roriz, M.; Chabriat, H.; Buffon-Porcher, F.; Cognat, E. Differential Diagnosis between Sarcoidosis and Granulomatosis with Polyangiitis in a Patient with Leptomeningeal, Cavernous Sinus and Pituitary Lesions. QJM 2017, 110, 691-692. [CrossRef]

210. Sève, P.; Pacheco, Y.; Durupt, F.; Jamilloux, Y.; Gerfaud-Valentin, M.; Isaac, S.; Boussel, L.; Calender, A.; Androdias, G.; Valeyre, D.; et al. Sarcoidosis: A Clinical Overview from Symptoms to Diagnosis. Cells 2021, 10, 766. [CrossRef] [PubMed]

211. Bouvry, D.; Uzunhan, Y.; Naccache, J.-M.; Nunes, H.; Brillet, P.-Y.; Valeyre, D. Sarcoïdose à présentation atypique. Rev. Méd. Interne 2008, 29, 46-53. [CrossRef] [PubMed]

212. Khan, A.; Al-Jahdali, H.; Rajiah, P.; Koteyar, S.; Allen, C. Atypical Radiological Manifestations of Thoracic Sarcoidosis: A Review and Pictorial Essay. Ann. Thorac. Med. 2013, 8, 186. [CrossRef]

213. Criado, E.; Sánchez, M.; Ramírez, J.; Arguis, P.; de Caralt, T.M.; Perea, R.J.; Xaubet, A. Pulmonary Sarcoidosis: Typical and Atypical Manifestations at High-Resolution CT with Pathologic Correlation. RadioGraphics 2010, 30, 1567-1586. [CrossRef]

214. Meenakshi, M.; Arnold, C.; Broadley, S.A. The Value of [18F]-Fluorodeoxyglucose-Positron Emission Tomography/CT Scanning in the Diagnosis of Neurosarcoidosis. J. Clin. Neurosci. 2012, 19, 1461-1462. [CrossRef] [PubMed]

215. Lococo, F.; Muoio, B.; Chiappetta, M.; Nachira, D.; Petracca Ciavarella, L.; Margaritora, S.; Treglia, G. Diagnostic Performance of PET or PET/CT with Different Radiotracers in Patients with Suspicious Lung Cancer or Pleural Tumours According to Published Meta-Analyses. Contrast Media Mol. Imaging 2020, 2020, 1-7. [CrossRef]

216. Moller, D.R.; Koth, L.L.; Maier, L.A.; Morris, A.; Drake, W.; Rossman, M.; Leader, J.K.; Collman, R.G.; Hamzeh, N.; Sweiss, N.J.; et al. Rationale and Design of the Genomic Research in Alpha-1 Antitrypsin Deficiency and Sarcoidosis (GRADS) Study. Sarcoidosis Protocol. Ann. Am. Thorac. Soc. 2015, 12, 1561-1571. [CrossRef]

217. Neuschlova, M.; Vladarova, M.; Kompanikova, J.; Sadlonova, V.; Novakova, E. Identification of Mycobacterium Species by MALDI-TOF Mass Spectrometry. Adv. Exp. Med. Biol. 2017, 1021, 37-42. [CrossRef] 